\title{
De máscaras y espejos: la iconotropía del diablo medieval en el códice Glasgow ms. Hunter 242*
}

\section{The mask and the mirror: the iconotropy of the medieval devil in the Glasgow Codex ms. Hunter 242}

\author{
Rosa Denise Fallena Montaño \\ Instituto de Investigaciones Estéticas, Centro de Extensión Oaxaca \\ Universidad Nacional Autónoma de México
}

Fecha de recepción: 14 de marzo de 2020

Fecha de aceptación: 27 de agosto de 2020
Anuario del Departamento de Historia y Teoría del Arte vol. 32, 2020, pp. 47-70

ISSN: 1130-5517, eISSN: 2530-3562

https://doi.org/10.15366/anuario2020.32.003

\begin{abstract}
RESUMEN
El propósito de este artículo es analizar las construcciones iconográficas y los procesos iconotrópicos de la figura del diablo en los dibujos del manuscrito Glasgow Hunter 242, elaborado alrededor de 1583 por artistas de la provincia indígena de Tlaxcala en la Nueva España. En virtud de la amplia polisemia y de su paradójica naturaleza, el diablo ha tenido una iconografía mutante y discontinua. Esto permitió que, según los discursos de la idolatría durante la evangelización de la Nueva España, Lucifer se ocultara bajo la forma de los "falsos dioses" con la intención de engañar a los indígenas. Sin embargo, a la vez, en estos dibujos se revela una lectura más profunda sobre la adaptación de las imágenes de las deidades nahuas en una nueva realidad en la segunda mitad del siglo XVI.
\end{abstract}

\section{PALABRAS CLAVE}

Iconotropía. Diablo. Idolatría. Dioses prehispánicos. Tlaxcala.

\begin{abstract}
The purpose of this article is to analyse the iconotropic processes of the devil's figure in the drawings of the Glasgow Hunter 242 manuscript, illustrated around 1583 by artists from the indigenous province of Tlaxcala in New Spain. By virtue its broad polysemy and its paradoxical nature, the devil has deserved a mutant and discontinuous iconography. According to the discourses of idolatry during the first evangelization of New Spain, Lucifer took the shape of the "false gods" with the intention of deceiving the indigenous people. At the same time, however, these drawings allow a deeper reading on the adaptation of the images of Aztec Deities to a new reality in the second half of the $16^{\text {th }}$ century.
\end{abstract}

\section{KEY WORDS}

Iconotropy. Devil. Idolatry. Pre-Columbian Gods. Tlaxcala.

\footnotetext{
* La elaboración de este artículo fue realizada con el apoyo de la DGAPA-UNAM y es producto del proyecto PAPIIT IN401720.
} 


\section{Introducción}

Es bien sabido que, después de la conquista y durante el proceso de evangelización en la Nueva España, los dioses prehispánicos fueron vistos como personificaciones del diablo. Esto corresponde a una construcción discursiva escatológica y apocalíptica, según el mensaje doctrinal principalmente elaborado por los misioneros que seguían los modelos e ideales de la tradición retórica cristiana medieval. En esta, el indio y sus prácticas eran "imaginados" bajo diferentes ópticas eurocentristas, tal como se advierte en las crónicas y documentos del siglo XVI, según apunta Guy Rozat Dupeyron¹.

Considerando lo anterior, me parece apremiante hacer una exploración más detallada y profundizar en casos específicos con el propósito de comprender el amplio espectro que ocuparon las diferentes versiones iconográficas de la imagen del Maligno en los discursos novohispanos. En este estudio me enfocaré en la representación del diablo y del pecado de idolatría dentro de la construcción retórica de fundación, a posteriori, elaborada por la nobleza tlaxcalteca en la segunda mitad del siglo XVI. En particular, me interesa ahondar en las asimilaciones iconográficas de la figura del diablo tardomedieval con las deidades nahuas en el Altiplano Central de México en las pictografías del manuscrito Glasgow Hunter 242. Para este estudio, encuentro pertinente el concepto de "iconotropía" definido por el historiador William J. Hamblin como "mal interpretación accidental o deliberada de las imágenes o de los mitos de una cultura ajena o diferente, especialmente con la intención de asimilarlos de acuerdo a valores propios" 2 . Cabe agregar que este artículo es parte de una investigación más amplia sobre el traslado y readaptaciones de las imágenes religiosas provenientes de la tradición medieval en la Nueva España.

El diablo ha sido a lo largo de la historia del pensamiento judeocristiano una entidad compleja, polisémica e inclusive contradictoria, tanto en sus conceptos como en sus representaciones. Sus características discursivas e iconográficas han sido constantemente cambiantes y su figura se ha usado para personificar al mal desde diferentes puntos de vista. Debido a su cualidad de transformación y plasticidad en diferentes temporalidades, el diablo ha asumido características de númenes o deidades de diferentes culturas de la Antigüedad, o bien, elementos distorsionados, exagerados o infamantes de los contrarios a la fe de Cristo o enemigos de la Iglesia. En palabras de Luther Link: "el diablo puede adoptar diferentes máscaras, pero en esencia es una entidad sin rostro"3.

Dentro de los esquemas europeos, el mal y el diablo ya traían consigo una larga historia de debates y contradicciones que hundía sus raíces en los primeros siglos del cristianismo dentro de la tradición patrística y que continuó durante la Edad Media, sobre todo en las argumentaciones tomistas a partir del siglo XIII. En efecto, los complejos dilemas para definir el mal y a Luzbel se proyectaron en las dificultades para su representación visual, que se caracterizó por una iconografía discontinua e inestable ${ }^{4}$. Es cierto que en el siglo XVI ya existía una tradición iconográfica más o menos homogénea y definida, sobre todo gracias a la reproductibilidad de las imágenes en las técnicas del grabado y de la imprenta. No obstante, el diablo continuaba siendo una entidad mutante que para el siglo XVI se había asociado especialmente con la idolatría, la hechicería, la brujería y con los reformistas, que, a ojos de los católicos fieles al poder papal, eran vistos como apóstatas y herejes ${ }^{5}$.

\footnotetext{
1 Guy Rozat Dupeyrion, Indios imaginarios e indios reales en los relatos de la Conquista de México, Veracruz, Universidad Veracruzana, 2010, p. 99.

2 William J. HAMBLIN, "Iconotropy and the JS Abraham Facsimiles", The Interpreter Foundation, 7 de abril de 2013. https://interpreterfoundation.org/blog-iconotropy-and-the-js-abraham-facsimiles/ [consulta: septiembre de 2019]. La traducción es mía.

3 Luther Link, Devil: A Mask Without a Face, Londres, Reaktion Books, 1995, pp. 15-16.

4 Ibidem, p. 35.

5 "La mayoría de los demonólogos del siglo XVI ven en la brujería un crimen de idolatría y de culto al demonio. En otras palabras, en el Malleus [Maleficarum] el crimen de brujería es, primero y, ante todo, un delito contra la naturaleza, la caridad y la raza humana, mientras que en las obras posteriores se convierte, en mayor medida, en un delito contra Dios y su Iglesia". Fernando CERVANTES, El diablo en el Nuevo Mundo. El impacto del diabolismo a través de la colonización hispanoamericana, Barcelona, Herder, 1996, p. 40.
} 
Huelga decir que los conquistadores y evangelizadores vieron las prácticas e imágenes indígenas extrañas, grotescas o aberrantes. Sin embargo, bajo el sistema de creencias cristianas y de las tradiciones grecolatinas, trataron de darle sentido a ese mundo totalmente nuevo y ajeno, intentando así encontrar coincidencias y semejanzas, proyectando sus propias concepciones. Las creencias populares provenientes del Viejo Continente permearon en el pensamiento novohispano dando lugar a iconografías locales donde quedaron amalgamadas las distintas tradiciones europeas y mesoamericanas ${ }^{6}$.

No es de extrañar que, en el siglo XVI, el diablo, con su característica proclividad a la mutación, fácilmente asumiera distintivos propios de los dioses mesoamericanos con el propósito de representar, según las creencias cristianas, el pecado de idolatría en el que supuestamente incurrían los indígenas como consecuencia de los embustes del Maléfico. Sin embargo, estas representaciones de los dioses-demonios no fueron, como se ha tratado de generalizar, arbitrarias o superficiales, tuvieron una lógica precisa y propósitos definidos. Tal como aquí intentaré demostrar, las adaptaciones iconográficas del diablo introducido en la "historia" de la Conquista corresponden, más bien, a la intención de representar el "mito cristiano" de la fundación de América entendido como un hecho providencial en donde tuvo lugar el enfrentamiento de las fuerzas del bien y del mal para que se cumpliera el plan de la salvación, según los esquemas discursivos europeos provenientes de las interpretaciones exegéticas de las Sagradas Escrituras ${ }^{7}$. Pero también corresponden a las adaptaciones de las prácticas religiosas indígenas, dentro de la construcción de los imaginarios ante una nueva realidad.

El concepto del demonio y sus imágenes fueron nuevos en el mundo mesoamericano, no existía ninguna entidad que fuera similar al diablo o que representara solamente la maldad. Asimismo, la idea moral del Dios cristiano estaba ausente en las deidades nahuas. En la cosmovisión mesoamericana todos los dioses tenían aspectos positivos y negativos; además, se presentaban bajo distintas identidades, nombres y formas. La relación entre belleza, verdad y virtud no tenía sentido en el sistema de valores de Mesoamérica. Por lo tanto, la figura de Satanás y sus secuaces se introdujo como algo totalmente diferente en las creencias y en la visualidad indígena. En cambio, para los ojos de los misioneros, la multiplicidad y variabilidad de los dioses correspondía, más bien, al engaño del Príncipe de las tinieblas. El proceso de asimilación y readaptación de la figura del diablo en las mentalidades indígenas es un tema por demás complejo porque su recepción y representación fue variando a lo largo del periodo colonial y en las localidades del vasto territorio novohispano. Sin duda esto implica grandes retos para la historia, la historia del arte y la antropología, y excede la propuesta de este trabajo ${ }^{8}$.

Para este estudio se ha realizado una revisión iconográfica del corpus de imágenes del diablo del siglo XVI que aún se conservan en la pintura mural conventual, en el arte rupestre y en los códices y pictografías coloniales en México, principalmente en el Altiplano Central. También se revisaron las descripciones demoniacas en las crónicas de los misioneros y en algunos documentos inquisitoriales de la segunda mitad del siglo XVI. Como resultado de este análisis se detectaron tres categorías tipológicas generales, a saber:

1) Diablos de la tradición tardomedieval del arte gótico. No hay que olvidar que estos modelos se trasladaron al Nuevo Mundo en su aspecto material en objetos transportables, como libros, pequeñas pinturas y estampas. Pero también, en las mentes y en la visualidad de los primeros europeos que llegaron a poblar las tierras indianas ${ }^{9}$. Por

\footnotetext{
6 A pesar de que en el humanismo la idea del mal se atribuía a las acciones humanas, el diablo siguió presente en la literatura, en el arte y en las creencias populares como el causante de todos los males. En el arte se siguió menos la teología, los artistas no se rigieron por los términos conceptuales. La figura grotesca del diablo en la que se combinaban rasgos humanos y de animales alcanzó su apogeo en los siglos XV y XVI. Jeffrey BurTon Russell, Lucifer: The Devil in the Middle Ages, Nueva York, Cornell University Press, 1988, pp. 208-209.

7 Rozat Dupeyrion, 2010, p. 139.

8 Sobre la recepción del diablo en el mundo amerindio ver CERVANTES, 1996, pp. 67-114.

9 "En este sentido las imágenes externas son percibidas por el cuerpo (mente) que actúa como 'medio viviente' que permite que se perciban, proyecten y se recuerden, así hay una relación de continuo intercambio entre las imágenes internas y externas. En este proceso, del lenguaje se convierten en imágenes mentales. Hay una diferencia entre el lenguaje oral y la escritura: el lenguaje oral necesita un organismo vivo, mientras que la escritura requiere el libro como soporte físico en el cual leemos en lugar de oír
} 
ejemplo, los programas pictóricos y escultóricos de la arquitectura eclesiástica, sobre todo del siglo XV, que estaban en la memoria de los misioneros, y que, a su vez se "materializaron" mediante descripciones, dibujos y esquemas que mostraban a los indígenas y que se incorporaron paulatinamente en su repertorio visual ${ }^{10}$.

Aunque se consideraba la verdadera naturaleza del diablo invisible y amorfa, mediante su iconografía de aspecto monstruoso se mostraba su depravación interna ${ }^{11}$. Estas figuras del Maligno europeo son entidades híbridas entre animal y ser humano, generalmente de color negro o rojo, están desnudas (en algunos ejemplos visten faldellín), sus cuerpos están cubiertos de pelo o escamas, tienen pezuñas o garras de tres o cuatro dedos, rabo que puede terminar en sierpe, orejas puntiagudas y cuernos, membranas dragoniles en las extremidades, muestran la lengua o gesticulan exageradamente y, algunos de ellos, despliegan alas de murciélago. Con frecuencia estos personajes están ubicados dentro de programas narrativos claramente europeos y tienen un propósito doctrinal o a manera de exempla ${ }^{12}$. Por ejemplo, el Juicio Final o los tormentos del infierno en la capilla abierta del convento agustino de San Nicolás Tolentino en Actopan (fig. 1) $)^{13}$.

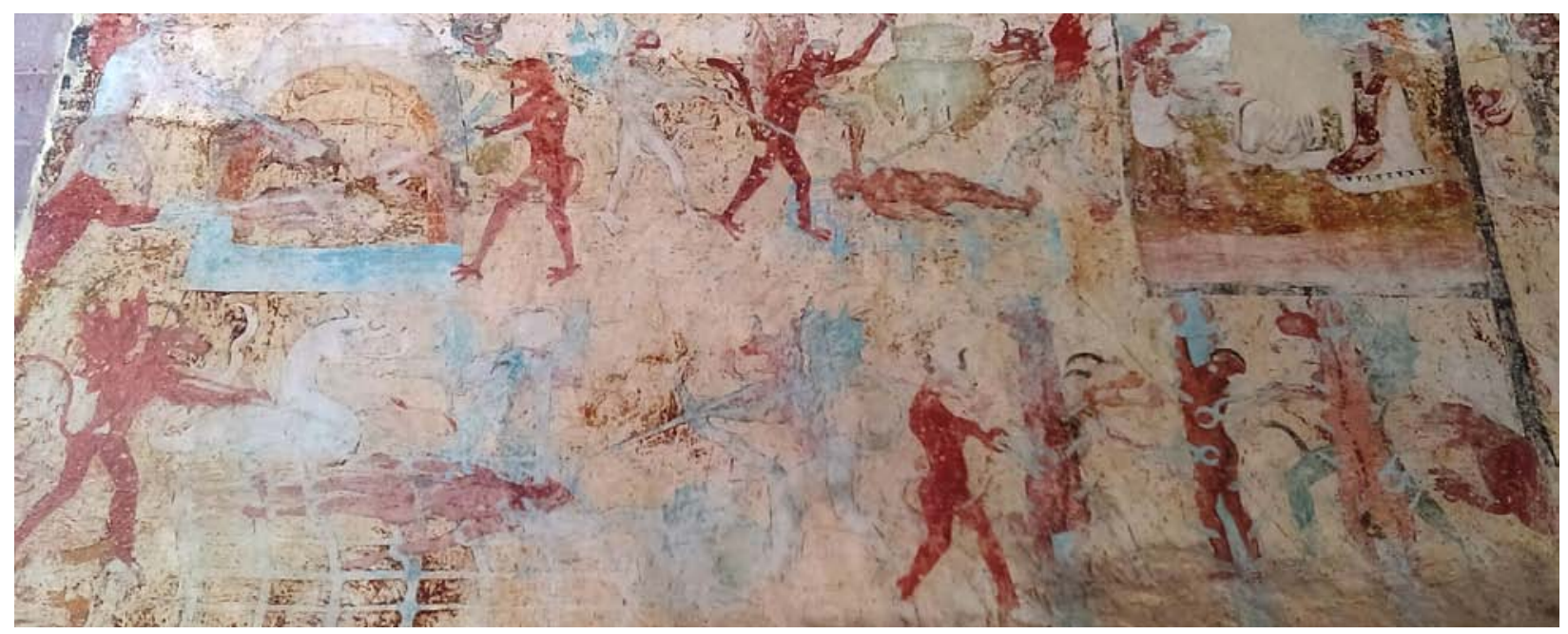

Fig. 1. Tormentos del infierno (detalle). Anónimo, mural del muro norte de la Capilla Abierta del Templo y exconvento de San Nicolás de Tolentino, siglo XVI, Actopan, Hidalgo (México). Fotografía de RubeHM CC BY-SA 4.0 https://creativecommons.org/licenses/by-sa/4.0/deed.en

la voz, al igual que sucede cuando vemos las imágenes. De manera semejante se ‘leen’ las imágenes cuando las diferenciamos de su medio. También las imágenes se escuchan cuando vienen acompañadas de algún sonido. Las imágenes 'viven' en su medio, del mismo modo que vivimos en nuestro cuerpo. Así por ejemplo las imágenes en su soporte proveen un cuerpo simbólico a entidades que no lo tienen como a los dioses o a los muertos. Por lo tanto, se puede hablar de 'intercambios-simbólicos', como menciona Baudrillard, entre el cuerpo muerto y la imagen viva. Así también, apunta al proceso de consagración para convertir un objeto en imagen y su materia se transformaba en su medio". Hans Belting, "Toward an anthropology of the image", en M. Westermann (ed.), Anthropologies of art, Williamston, Sterling and Francine Clark Art Institute, 2005, pp. 41-58. La traducción es mía.

10 Un ejemplo muy temprano es el catecismo elaborado por fray Pedro de Gante entre 1525-1528, actualmente en la Biblioteca Nacional de España (Madrid) que contiene dibujos esquematizados para ilustrar la doctrina cristiana.

11 En las creencias populares se afirmaba que el diablo podía tomar la forma de animales, personas o criaturas monstruosas. BuRTON RusSELL, 1988, pp. 67-68 y pp. 130-132. Se ha discutido si estas características de la representación del diablo provienen del dios de los bosques greco-romano, Pan. La desnudez está relacionada con sus poderes sexuales y de lascivia, y es probable que recuerde a la desnudez de los dioses clásicos. En el arte románico y gótico hay ejemplos que tienen rostro en el abdomen o en las nalgas, lo que acentúa su condición monstruosa. A finales del siglo XIV se popularizó el demonio con alas negras de murciélago en contraste con las alas con plumas blancas o de variados colores de los ángeles representados como seres de luz. LiNK, 1995, 50-67.

12 Se han encontrado pinturas del diablo con características europeas en cuevas junto a o sobre pinturas religiosas indígenas anteriores a la Conquista. Ver Fernando BerRoJALBIZ, "Evolución de un lugar sagrado en el Istmo de Tehuantepec durante la colonia: cruces pictográficas, verae effigies y conjuros satánicos", Anales del Instituto de Investigaciones Estéticas, vol. XXXIX, n 116 (2020), pp. 171-220.

13 En los murales del ex convento de Santa María Xoxotenco se observan diablos con iconografía gótica tentando a los indígenas. Sin embargo, sigue siendo un discurso de tradición europea. 
2) Diablos tardomedievales (como en el punto anterior), o bien figuras que aluden a dioses grecolatinos pero están ubicadas como dioses-ídolos en templos o altares prehispánicos ${ }^{14}$. En estas representaciones se traslada al mundo americano el tropo medieval de la adoración de los ídolos paganos de la Antigüedad. Tal como ha estudiado Michael Camille, en la retórica medieval el ídolo fue una manera de personificar a los "otros", ya sean estos, paganos, infieles o herejes, inclusive, a los mahometanos y a los judíos, cuyas religiones se caracterizan por ser anicónicas. Esta práctica continuó en los siglos XV y XVI para personificar a las brujas, a los hechiceros, herejes y apóstatas. En América, se usó para representar a los indígenas antes de la llegada de los europeos, o bien a los que se negaban a aceptar el cristianismo y continuaban con sus prácticas religiosas. El tropo de la adoración de los "falsos dioses" fue una figura retórica particularmente dirigida a la condena de la idolatría como una de las peores argucias de Satán para perder a las almas de aquellos que se negaban a seguir al Redentor, en otras palabras, los enemigos de Cristo $^{15}$. En esta categoría distingo la lámina del Templo Mayor en el Códice florentino donde los dioses Tláloc y Hutzilopochtli carecen de la iconografía propia de los dioses mexicas; en cambio, tienen evidentes características del diablo tardomedieval (barbas de fauno, nariz prominente, orejas puntiagudas, garras y cabello flamígero y uno de ellos gesticula exageradamente), pero están ubicados en el gran templo doble, piramidal y escalonado de la ciudad de Tenochtitlan, que ocupa el lugar de los templos grecolatinos o sinagogas dentro del tropo medieval sobre la idolatría (fig. 2).

3) Dioses representados con iconografía de tradición indígena en códices que contienen las figuras de cada uno de los dioses del panteón nahua y la explicación de sus cultos y festividades, en un formato enciclopédico que recuerda a la obra de Plinio el Viejo, cuya información provino de informantes indígenas. Un caso por demás paradigmático es el Códice florentino. Algunos de los dioses son de aspecto atemorizante y aparecen como entidades activas en las prácticas religiosas indígenas, sobre todo el dios de la muerte Mictlantecuhtli o los tzitzimime ${ }^{16}$. O bien, como individuos de proporciones más o menos humanas, ataviados con los atributos propios de la deidad indígena que representan. En las inscripciones adjuntas se señala su nombre y se describe su culto y festividad. De esta manera la etiqueta de su nombre funciona para determinar su aspecto visual particular y establecer así una iconografía "reconocible". No obstante, en la gran mayoría de los casos, se les denomina como "demonios", "diablos" o "ídolos", lo que define su naturaleza maligna. Así pues, en este proceso los elementos iconográficos de tradición indígena también fueron asimilados en el repertorio

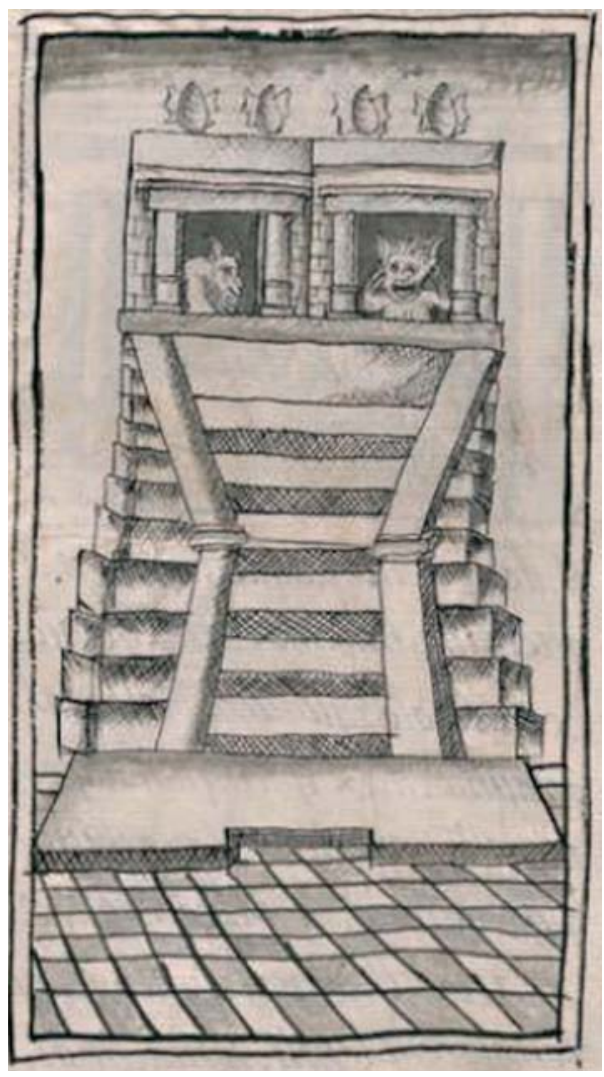

Fig. 2. Templo Mayor (detalle). Bernardino de Sahagún, Códice florentino o Historia general de las cosas de Nueva España, 1577, libro XI, volumen 3, Biblioteca Laurenciana, Florencia, Ms. Med. Palat. 220, f. 391v (detalle). Imagen digitalizada de la Biblioteca Medicea Laurenciana de Florencia.

14 En la tradición europea, los ídolos tienen en algunos casos características de babuinos o micos que se consideraban como simulacros aberrantes del ser humano hecho a imagen y semejanza de Dios.

15 Los ídolos en el arte gótico principalmente se representan como objetos tridimensionales a manera de simulacros de sus prototipos, referidos a las esculturas de los dioses grecolatinos y también como simios. Michael CAMILLE, El ídolo gótico. Ideología y creación de imágenes en el arte medieval, Madrid, Akal, 2000, p. 75.

16 Los tzitzimime eran entidades celestes del panteón mexica, estrellas belicosas relacionadas con la oscuridad y el caos primigenio, antagónicas al nacimiento del Sol y el tiempo. Cervantes, 1996, p. 74. 
de la visualidad europea, con sus obvias distorsiones y adaptaciones. Es el caso del dios Tezcatlipoca en el Códice Tudela (fig. 3) ${ }^{17}$.

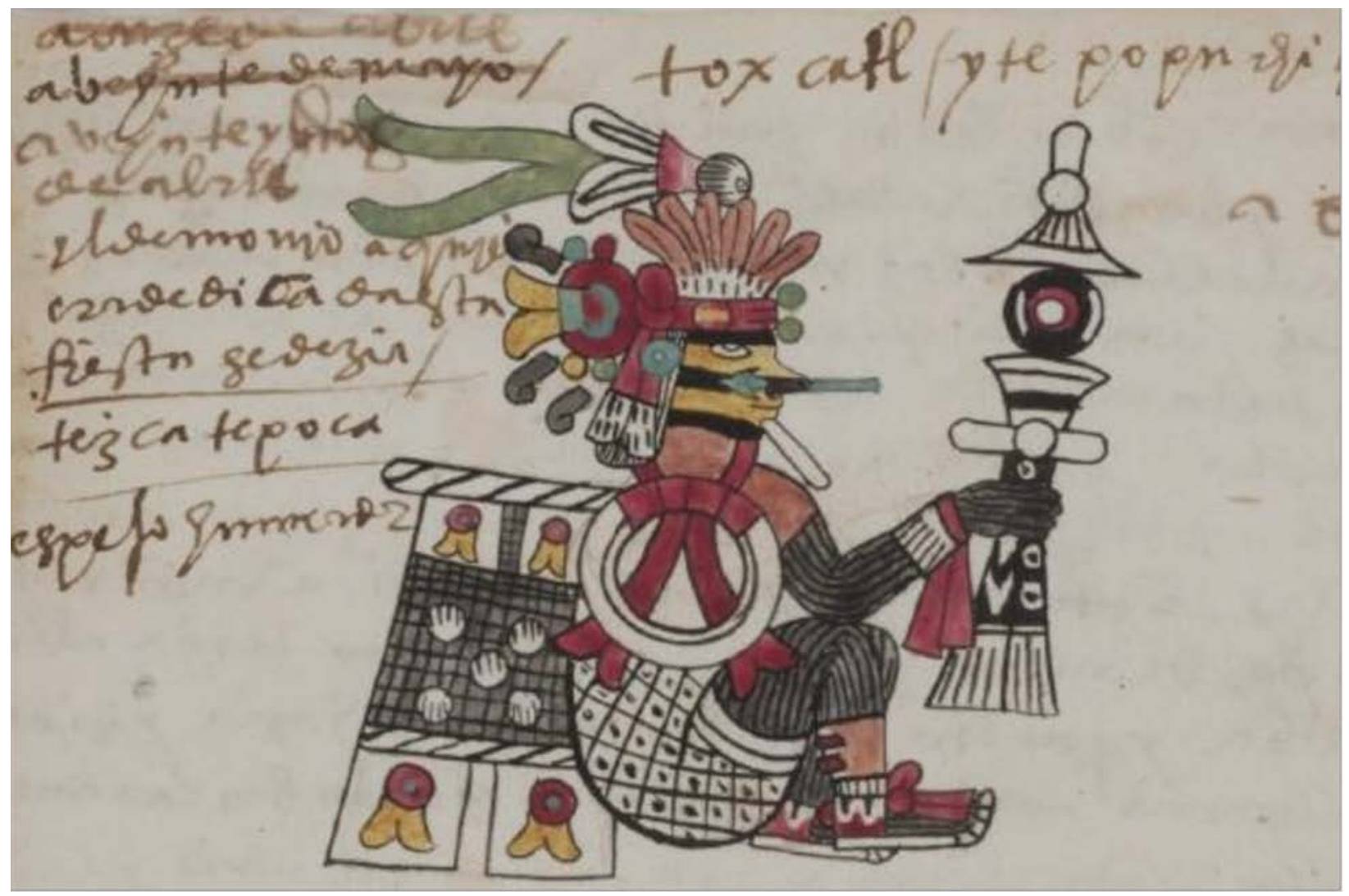

Fig. 3. Dios Tezcatlipoca, Anónimo (tlacuilo indígena), Códice Tudela, 1530-1554, Museo de América, Madrid, nº inv. 70400, f. 15r. Fotografía: Red Digital de Colecciones de Museos de España.

4) Personajes que comparten en una misma figura atributos iconográficos tanto del demonio gótico como de las deidades prehispánicas, representados dentro de espacios idolátricos o recién cristianizados en los territorios del Nuevo Mundo, y en cuya apariencia se integra la idea del "dios-ídolo-demonio". Es el caso de las tres láminas del manuscrito de Glasgow, objeto de este trabajo. Es cierto que estos dibujos han sido frecuentemente empleados como documentos para ilustrar el proceso de evangelización y destrucción de los cultos indígenas por los franciscanos. Pero, a mi parecer, merecen ser explorados bajo una lógica intrínseca a sus propias composiciones, dentro de una lectura más bien simbólica, y estudiados en el marco metodológico de la cultura visual ${ }^{18}$.

17 Un caso por demás revelador que aglutina diversos elementos del imaginario grecolatino, medieval e indígena es el grabado del ídolo-demonio-fauno con alas de murciélago en la obra Rethorica cristiana de fray Diego Valadés, adorado por los indígenas en un templo con elementos arquitectónicos "a la romana".

18 El término "cultura visual”, propuesto por W.J. Mitchell, plantea la necesidad de dotar a los estudiosos de los objetos visuales de un conjunto de herramientas críticas para la investigación de la visualidad humana y no transmitir solamente un cuerpo específico de información o valores. Por su parte Keith Moxey agrega que "el estudio académico de las imágenes es el reconocimiento de su heterogeneidad, de las siguientes circunstancias de su producción, y de la variedad de funciones culturales y sociales a las que sirve. Es precisamente debido al hecho de que la parafernalia interpretativa, las estrategias heurísticas, que se usan para la elucidación de diferentes tradiciones de producción visual sean radicalmente distintas unas de otras, que cada forma de investigación tiene mucho que ganar estando en contacto con las otras". Keith MoXEY, "Nostalgia de lo real. La problemática relación de la historia del arte con los estudios visuales", Estudios visuales, no 1 (2003), pp. 47-48. 


\section{El manuscrito Glasgow Hunter $242^{19}$}

El manuscrito Glasgow Hunter 242, que trata sobre la descripción e historia de la provincia y ciudad de Tlaxcala, fue elaborado entre 1580 y 1583 por regia petición de Felipe II al virrey don Martín Enríquez de Almansa (1508/1511-1583) con el propósito de conocer las distintas regiones de sus vastos dominios en las Indias occidentales. A su vez, el virrey Enríquez encomendó el encargo al alcalde mayor de la ciudad capital de dicha provincia, el cacique indígena don Alonso de Nava. El manuscrito finalmente fue elaborado por el historiador, también tlaxcalteca, Diego Muñoz Camargo (1529-1599) ${ }^{20}$.

En 1584 el gobernador en funciones, don Antonio Guevara, y el alcalde mayor de Tlaxcala, don Alonso de Nava, acompañados por una comitiva de nobles tlaxcaltecas, viajaron al Viejo Continente con la intención de ofrecer vasallaje al rey Felipe II y entregaron al monarca el manuscrito ${ }^{21}$. También los acompañó Diego Muñoz Camargo, quien fue el intérprete entre los nobles tlaxcaltecas y el rey en virtud al buen dominio de la lengua náhuatl. Así el manuscrito fue resguardado en la Real Librería hasta el siglo XVIII ${ }^{22}$.

Muñoz Camargo era mestizo, hijo de padre peninsular y de madre indígena, pero fue educado "a la española" 23 . Para la elaboración de su escrito tuvo conocimiento de algunas obras importantes de los misioneros franciscanos, tal como claramente expresó al inicio de su obra: "Fray Andrés de Olmos, fray Bernardino de Sahagún, frailes de la orden de San Francisco, fray Jerónimo de Mendieta y el padre Toribio de Benavente Motolinía a los cuales conocí y conozco y vi parte de sus obras escritas de mano, los cuales con mucho cuidado y entendimiento supieron $[\mathrm{y}]$ entendieron muchos secretos de los naturales" 24 .

La Descripción e historia de Tlaxcala contiene 157 láminas con dibujos en tinta con algunos detalles a color (rojo, amarillo, verde y gris) que sirven para acentuar motivos particulares como la sangre, el fuego y el lodo.

19 El título completo del manuscrito es Descripción de la Ciudad y Provincia de Tlaxcala de las Indias y del Mar Océano para el buen gobierno y ennoblecimiento dellas. Ficha bibliográfica:

Núm. de signatura Glasgow Hunter 242 (U.3.15)

Papel, 21 x 29 cm, ff. 327, originalmente ff. 334, escrito a mano, a una columna alrededor de 20 líneas por página. Márgenes rojos, paginación contemporánea (ff. 1-237). Dos blasones de página completa, uno del rey Felipe II y otro aún no identificado. Dibujos con pluma y tinta (157) a partir del folio 236r. Dos insertos de diagramas astronómicos a color (entre ff. 177v y 178r). Tiene anotaciones al margen y hay indicios de daño por humedad. Encuadernado en piel de becerro con cordones de cuero y broches, cantos dorados y sobre el lomo está escrito en tinta: FLAXACALA. La fecha de elaboración en el catálogo es a finales del siglo XVI (Late Cent. XVI). La traducción es mía.

20 "Dando principio a la relación que vuestra Majestad mandó se haga acerca de la descripción de esta tierra conforme a la instrucción que esta ciudad de Tlaxcala envió don Martín Enríquez Virrey que fue de esta Nueva España, Alonso de Nava Alcalde mayor de ella el cual me cometió siguiese con diligencia y ocupado y tres diese a los capítulos de la manera y orden que vienen expresados tocantes a esta provincia". Diego MuÑoz CAMARGo, ms. Glasgow Hunter 242, f. 1v.

21 Es probable que el manuscrito fuera entregado como regalo de introducción o de despedida. Diego MuÑOz CAMARGO, Descripción de la Ciudad y Provincia de Tlaxcala de las Indias y del Mar Océano para el buen gobierno y ennoblecimiento dellas (edición facsimilar del Ms. de Glasgow, con estudio preliminar de René Acuña), México, Instituto de Investigaciones FilológicasUNAM, 1981, pp. 12-13.

22 Se ignoran las circunstancias, pero se sabe que fue extraído y adquirido por el médico escocés William Hunter (17181783 ) en el siglo XVIII; después de su muerte fue donado a la Biblioteca de Glasgow en Escocia en donde permanece hasta nuestros días.

${ }_{23} \mathrm{Su}$ padre fue el conquistador del mismo nombre quien acompañó a Hernán Cortés a la expedición de las Hibueras (Honduras) y recibió del virrey don Antonio de Mendoza, para premiar sus méritos militares, el paraje en los valles de Atzompa en Tlaxcala. Existe gran controversia para establecer el linaje y las relaciones de parentesco del historiador Diego Muñoz Camargo, sin embargo, lo que me interesa remarcar para efectos de este trabajo es la construcción de la identidad que hace el autor mediante su relato en el manuscrito, sin la pretensión de profundizar la verdad histórica de su linaje. El autor reconoce en todo momento la ayuda de los tlaxcaltecas para que tuviera lugar la victoria sobre los indígenas enemigos, es decir, aquellos que no aceptaron la sumisión ante las fuerzas extranjeras y que se negaron a la cristianización. Por otro lado, tal como él mismo expresa en las primeras páginas del manuscrito, nació y residió 35 años en la provincia de Tlaxcala y fue nombrado teniente del alcalde mayor por lo que conocía a detalle su territorio, historia y costumbres. MuÑoz CAMARGO, ms. Glasgow Hunter 242, f. 9r.

24 Muñoz Camargo, ms. Glasgow Hunter 242, f. 17r. 
A este conjunto algunos autores lo llaman Códice de Glasgow ${ }^{25}$. Es posible que varios de los dibujos fueran copias de las pinturas realizadas alrededor de 1552 que estaban en los muros de la "casa de los alcaldes mayores y jueces" que albergaba la sala de cabildos y el recinto para principales, tal como se dice en el manuscrito, o bien, copias del Lienzo de Tlaxcala. Sin embargo, es probable que algunos dibujos provengan de fuentes que desconocemos. Cabe remarcar que la ubicación de las pinturas en este sitio de mando e impartición de justicia las legitimaba y les confería un alto valor dentro de la retórica de las glorias de la provincia tlaxcalteca.

En las pinturas referidas por Muñoz Camargo en las casas de gobierno se dice que "narraban en vivos colores" la historia de la Conquista y pacificación desde la llegada de los europeos y el papel protagónico que desempeñaron los tlaxcaltecas para otras conquistas posteriores en los territorios novohispanos ${ }^{26}$. La ausencia de color de los dibujos del Códice de Glasgow me intriga. Sospecho que esta peculiaridad tiene significados que aún no se han determinado. ¿Acaso la línea de contorno sin colores alude a la idea mesoamericana del final de una era y el inicio de otra, es decir, el tiempo intermedio, confuso y en formación, que se ha denominado como "nepantlismo"?27.

Tal como han propuesto Gordon Brotherston y Ana Gallegos, el códice pictográfico que acompaña el manuscrito no es meramente ilustrativo, inclusive, no hay una intención directa de correspondencia en la línea temporal del relato con las láminas de los dibujos, sino que, más bien, estos complementan y enriquecen el discurso simbólico ${ }^{28}$. En estos dibujos se aprecian las convenciones pictóricas de la tradición europea que ya se habían implantado en tierras novohispanas a finales del siglo XVI. Los dibujos están realizados mediante una línea sólida, continua y precisa que sigue las reglas del dibujo europeo. Se sugiere el volumen por medio de sombreados y la idea de perspectiva se logra con la yuxtaposición de diferentes planos o líneas fugadas. Todos los dibujos están encuadrados por un marco que evoca la ventana albertiana, y en el margen inferior tienen una inscripción explicativa en castellano ${ }^{29}$. Por otro lado, aparecen elementos iconográficos claramente de raigambre indígena, especialmente de la tradición nahua del centro de México, y encuentro claras semejanzas con los códices producidos durante el siglo XVI, especialmente con el Códice florentino y los códices Telleriano-Remensis, Tudela, Tovar y Durán. Para este artículo me centro en tres láminas: La destrucción del templo idolátrico, La imposición de la cruz por los doce religiosos y La quema de los ídolos.

\section{La destrucción del templo idolátrico. Tezcatlipoca, el espejo de Lucifer}

La introducción de las imágenes cristianas y su culto de ninguna manera fue una simple sustitución, como erróneamente suele pensarse, sino un proceso complejo de largo aliento y, en muchas ocasiones, violento. A partir de 1530, fecha en que se instituyó la inquisición, los franciscanos destruyeron templos y objetos que consideraron idolátricos, ante la decepción de la reincidencia de los indígenas en los "cultos idolátricos". Varios señores de la nobleza indígena o pipiltin, incluyendo tlaxcaltecas, fueron acusados y

\footnotetext{
25 Diana Magaloni argumenta que "en náhuatl el concepto de registro de la historia mediante estas pinturas-sujeto [en el Códice florentino] se expresa con la metáfora in tlilli in tlapalli, 'la tinta negra, los colores', que se usa para nombrar, de acuerdo con Miguel León-Portilla, el conocimiento adquirido y acumulado por una cultura, su sabiduría. Por medio de sus materiales constitutivos: in tlilli, 'la tinta negra', hace alusión al contorno en línea de las figuras pintadas, mientras que in tlapalli, 'los colores', hace referencia a los pigmentos que las iluminan con sus brillantes tonos”. Diana Magaloni, Los colores del Nuevo Mundo. Artistas, materiales y la creación del Códice florentino, México, UNAM, Getty Research Institute, 2013, p. 18.

26 MuÑoz CAMARGO, ms. Glasgow Hunter 242, f. 12v.

27 "Nepantlismo" proviene del término náhuatl nepantl mencionado por un informante indígena en la obra de Durán y que significa "estar en medio", ni en un lado, ni en otro. Citado en CERVANTES, 1996, p. 91.

28 "Debidamente comparados estos dos textos, la Descripción alfabética y el Códice pictográfico, se observa que cada uno de ellos presentan características y lógicas propias a tal grado que se hace difícil pensar que uno dependa del otro. Más bien se complementan". Gordon Brotherston y Ana Gallegos, "El lienzo de Tlaxcala y el Manuscrito de Glasgow (Hunter 242)", Estudios de cultura náhuatl UNAM, nº 20 (1990), p. 120.

29 Magaloni, 2013, p. 16.
} 
procesados por idolatría. Hubo una cruenta represión, tal como menciona Motolinía ${ }^{30}$. En efecto, durante estos años muchos indígenas fueron ajusticiados, tal como se muestra en los dibujos de los folios 241v y $242 \mathrm{v}$ del Códice de Glasgow. En estas dos escenas se representa la pena de muerte para los idólatras reincidentes, pero en ningún caso aparece la figura del diablo ${ }^{31}$.

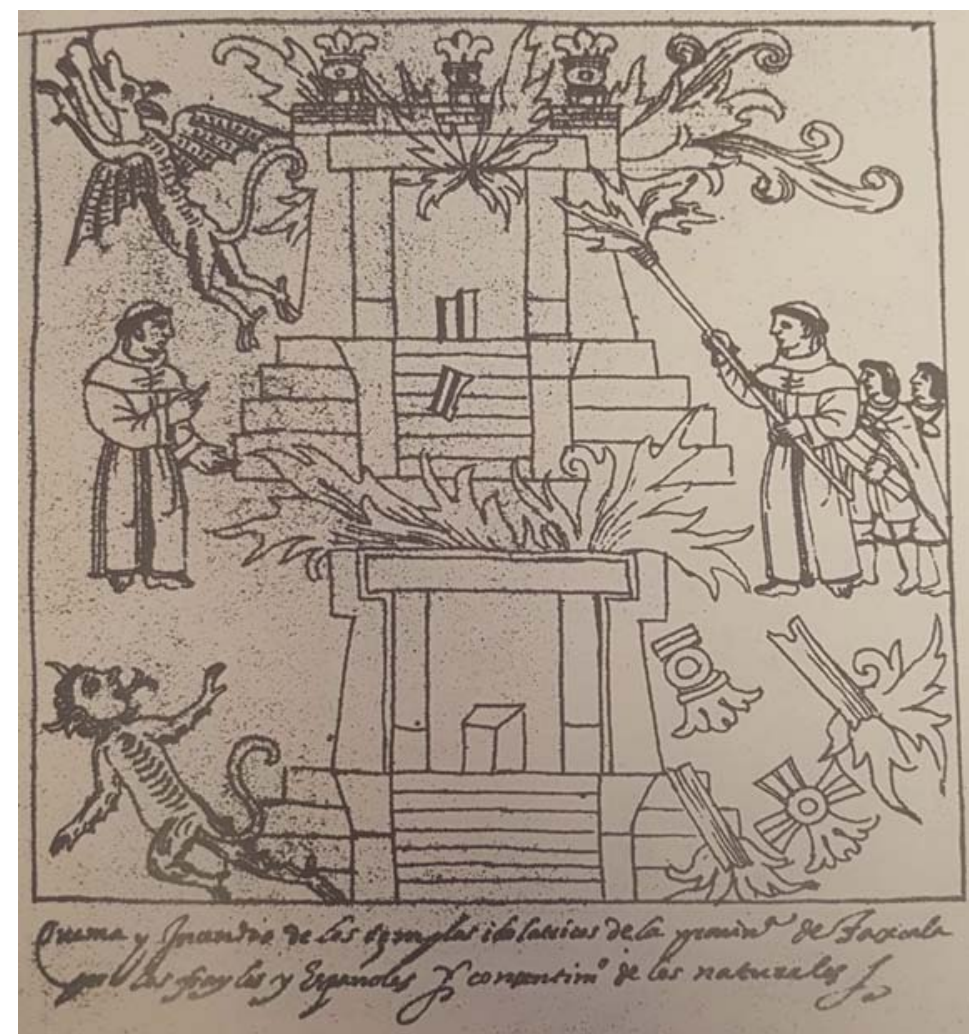

Fig. 4. Destrucción del templo idolátrico. Diego Muñoz Camargo, Descripción de Tlaxcala, ca. 1583, Biblioteca de la Universidad de Glasgow, Ms. Glasgow Hunter 242, f. 240v, dibujo a tinta, 21×29 cm. Fotografía de la edición facsimilar: Diego Muñoz Camargo, Descripción de la Ciudad y Provincia de Tlaxcala de las Indias y del Mar Océano para el buen gobierno y ennoblecimiento dellas, México, Instituto de Investigaciones Filológicas-UNAM, 1981.

Ahora bien, el margen inferior del folio 240v contiene escrita la siguiente explicación: "Quema y incendio de los templos idolátricos de la provincia de Tlaxcala por los frailes y españoles y consentimiento de los naturales" (fig. 4). En efecto, se representa a dos frailes franciscanos incendiando un par de templos piramidales similares al huey teocalli representado en el Códice florentino. Uno de los frailes es ayudado por un par de jóvenes nobles tlaxcaltecas cristianizados, tal como lo sugieren sus atuendos (visten camisa con

30 Fray Toribio Motolinía, El libro perdido, capítulo XXIX, E. O’Gorman (dir.), México, CONACULTA, 1989 , p. 422.

31 "Hacia la mitad del siglo XVI, el panorama tenía un aspecto muy distinto. Había triunfado una visión negativa y diabólica de las culturas amerindias, y su influencia se había ido filtrando como niebla espesa en todas las declaraciones hechas sobre el tema, ya fueran oficiales o no. Las razones para explicar este enigmático desarrollo son confusas y contradictorias”. CERVANTES, 1996, pp. 21-22. 
puños, calzón y tilma, llevan el cabello corto). Esta composición proviene de los programas iconográficos de origen medieval de la destrucción de los templos romanos, del templo de Jerusalén o del derrumbe de la sinagoga como metáfora del fin de la ceguera pagana o la conclusión de la ley mosaica. La caída del templo prehispánico, según el discurso simbólico escatológico, indica que es el fin del tiempo idolátrico en el Nuevo Mundo y el inicio de una nueva era en Cristo. Desde esta perspectiva, la violenta destrucción implica un mensaje esperanzador, ya que después vendría el renacimiento hacia la "verdadera fe" y, en esta retórica simbólica, los jóvenes representan la "nueva generación” de indígenas tlaxcaltecas cristianos ${ }^{32}$.

La destrucción de los ídolos es un tema literario y artístico sobre el aniquilamiento de los dioses paganos que se remota a los mandatos del papa Gregorio I Magno (540-604) con el propósito de terminar con la "semilla" de la idolatría, práctica abiertamente condenada por Pablo:

Si somos, pues, del linaje de Dios, no debemos pensar que la divinidad sea algo semejante al oro, la plata o la piedra, modelados por el arte y el ingenio humano, ni es servido por manos humanas, como si de algo estuviera necesitado, el que a todos da la vida, el aliento y todas las cosas (Hechos 17:24,25).

Llama la atención que en el dibujo del Códice de Glasgow los pedestales de los dioses aparecen vacíos y quebrados, no hay ningún simulacro o efigie de los dioses, como en el caso del templo del Códice florentino. ¿Acaso se sugiere que estos objetos ya han sido consumidos por el fuego? Pero a la vez, su ausencia puede aludir a la paradoja de que el mal, en última instancia, es la negación de todo bien, es decir, la nada, la no existencia, como había sostenido Pseudo Dionisio Areopagita (siglos V-VI).

En el lado izquierdo se incluye a un par de demonios de mayores dimensiones que huyen atemorizados ante el fuego purificador, a la vez que el edificio se derrumba en pedazos. Por medio de estos personajes se representan las "fuerzas activas" del mal supuestamente contenidas en los "falsos dioses", cuyas figuras materiales están ausentes. Con la destrucción de su simulacro material, que servía a guisa de disfraz, queda al descubierto el engaño de Satán y los demonios se dan a la fuga ${ }^{33}$.

En el caso de esta lámina, los diablos no tienen la intención de adoctrinar o atemorizar, más bien ilustran su derrota frente a la victoria del cristianismo en las tierras tlaxcaltecas. Aquí los diablos aparecen disminuidos y esquematizados. Sin embargo, cabe destacar que no son destruidos por completo ${ }^{34}$. Más bien, se les obligó a huir mediante el fuego y el poder de la predicación de la palabra de Dios, arma por demás poderosa, tal como se advierte en la figura del fraile con el dedo índice levantado que, según las normas de la retórica clásica, indica el discurso oral. En efecto el diablo y sus secuaces seguirán en el mundo tentando a las almas hasta el fin de los tiempos, solo con la parusía serán totalmente vencidos y confinados en los avernos para toda la eternidad (Ap 20:10). Por ello, solamente se pueden destruir sus simulacros o los artefactos donde se han introducido. La fe en Cristo representaba la manera efectiva de ahuyentarlos y de proteger al cristiano de sus embustes ${ }^{35}$.

32 Dentro del arte gótico, en la catedral de Amiens (fachada oeste, pórtico sur) destaca un relieve donde se mira la caída de un par de ídolos desde sus pedestales quebrados, al tiempo que se derrumba el templo pagano. La caída de Roma y Jerusalén, desde una lectura exegética, se consideró como una revelación y prefigura del fin de los tiempos y el advenimiento del reino de Dios. Rozat Dupeyrion, 2010, pp. 172-177.

33 De manera similar, en la biblia moralizada ms. Harley 1525 de la Biblioteca Británica, realizada en el siglo XIII, en los folios 77r y 105r solamente se representa el pedestal de los ídolos y se deja un espacio en blanco para los multos deos. Michael Camille especula que este hecho fue debido a la prohibición de la ley mosaica, al igual que los decretos de la Iglesia del siglo XIII, donde estaba contenida la condena por hacer falsos dioses. Los espacios vacíos en el manuscrito fueron una medida para evitar el pecado involuntario de los iluminadores de "hacer" ídolos o que algún lector pudieran hacer mal uso y adorarlos. O bien, pudo ser una manera de expresar que los ídolos son la antítesis de Dios y en realidad son la nada. CAMILLE, 2000, p. 39.

34 En su aspecto formal estos diablos del Códice de Glasgow guardan cierta semejanza con aquellos ilustrados como personificación de los vicios en la obra de Hans Vintler Das buoch der tugend (El libro de la virtud), publicada en 1486 en Augsburgo.

35 Burton Russell, 1988, p. 154. 


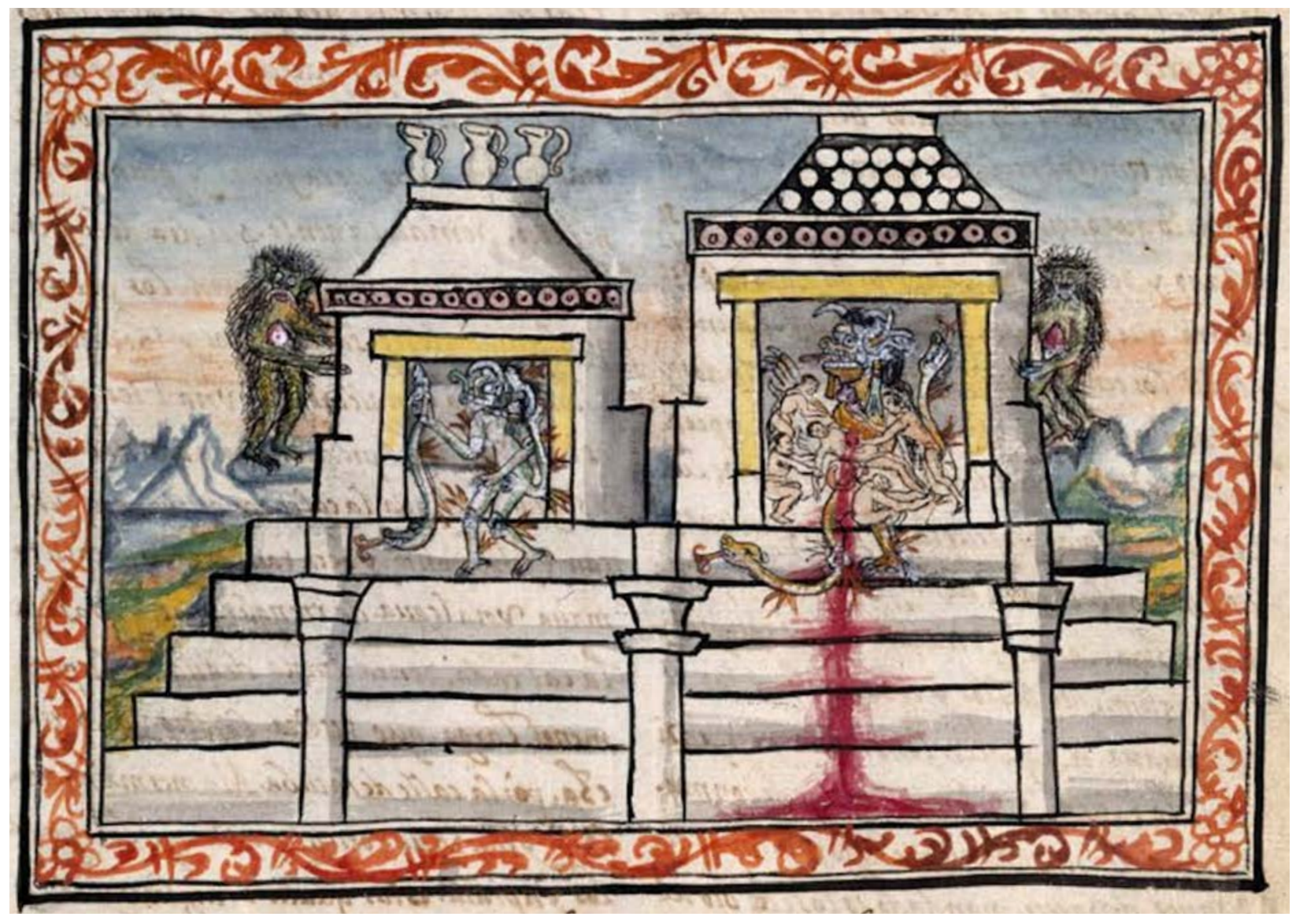

Fig. 5. Templo Mayor. Diego Durán, Códice Durán o Historia de las Indias de Nueva España e Islas de Tierra Firme, 1579, Biblioteca Nacional de España, Madrid, Ms. Vitr/26/11, f. 131r. Imagen digitalizada de la Biblioteca Nacional de España.

En la lámina del Templo Mayor de Tenochtitlán en el Códice Durán (fol. 131r), realizado en 1577, también se representa la distinción entre Satán como fuerza activa y los dioses-ídolos como receptáculos materiales (fig. 5). En este caso, el templo está en plena "actividad idolátrica" ya que se está efectuando un sacrificio humano. Nótese que en el dibujo del Códice de Glasgow no se ve a los indígenas haciendo sacrificios o adorando a sus dioses. Sospecho que su ausencia implica la intención de minimizar las prácticas religiosas anteriores de los tlaxcaltecas y, más bien, se enfatiza que ellos sí aceptaron el cristianismo, a diferencia de los tenochcas, y estuvieron dispuestos acabar con todas las prácticas idolátricas. En el interior de cada adoratorio del gran templo de Tenochtitlan se observan sendas figuras diabólicas de características europeas, pero si se miran con atención se advierten algunos atributos de los dioses patronales de Tenochtitlan. El dios-demonio del lado izquierdo, que sujeta una serpiente azul y monstruosamente tiene rostros en las coyunturas, se destaca por su nariz torcida, colmillos y anteojeras, por lo que se identifica como el dios del agua y la fertilidad Tláloc. Su compañero, en el adoratorio del lado derecho y de mayor dimensión, tiene rostro claramente diabólico y muestra la lengua; inclusive, por su visible cornamenta, recuerda al dios-toro Baal mencionado en la Biblia. Sin embargo, tiene orejeras, nariguera, bezote, pintura facial y tocado con plumas de garza (también distintivo de Tezcatlipoca), propios del dios de la guerra Hutzilopochtli. Junto a él se observan dos culebras en llamas (o una serpiente de dos cabezas en cada uno de sus extremos) que representan a la serpiente de fuego o xiuhcóatl. A la vez, en este dibujo las serpientes simbolizan el pecado en el pensamiento cristiano. Estos personajes son los simulacros de los "falsos dioses", es decir, los ídolos confeccionados por mano indígena para su adoración. En cambio, flotando y a 
manera de custodios un par de demonios peludos con una incisión en el pecho son las "fuerzas" de Satanás que activan al par de ídolos e inducen a los indígenas a idolatrarlos mediante acciones aberrantes, como el sacrificio. Es curioso que estos demonios cubiertos de pelo comparten iconografía con el "hombre salvaje" de tradición medieval y que representaba al "no civilizado", seres dominados por sus instintos bestiales. Cabe agregar que también se empleó este personaje, en su versión positiva, para representar a la candidez indígena, de manera idealizada, poco tiempo después del descubrimiento de América ${ }^{36}$.

A primera vista, los elementos formales e iconográficos de estas criaturas del mal en el Códice de Glasgow recuerdan a los diablos de finales del siglo XV presentes en las estampas y en los devocionarios. A pesar de su simplificación conservan las características iconográficas del maléfico propias de la tradición europea. Sin embargo, es importante revisar con atención los detalles de este par de diablos para notar que hay una construcción oportuna de coincidencias iconotrópicas entre el diablo europeo y ciertos dioses indígenas. Uno de ellos tiene hocico de cánido y alas de murciélago, ambos atributos propios del diablo gótico y de ciertas deidades indígenas. El otro tiene rostro o máscara humanoide, ostenta nariz prominente, cuernos, orejas puntiagudas y tiene la pierna izquierda de menor tamaño flexionada. Estas características nos ofrecen pistas para identificar sus identidades en el panteón nahua ${ }^{37}$.

Muñoz Camargo dedica varias páginas de su manuscrito a la leyenda de los dioses antagónicos Quetzalcóatl y Tezcatlipoca y supone, al igual que Bernardino de Sahagún, que estos personajes fueron en su origen caudillos gobernantes y que, por soberbia, tiempo después fueron adorados como dioses mediante sus simulacros ${ }^{38}$. Tezcatlipoca, el "dios malo" también llamado Huemac en el manuscrito de Glasgow, es descrito como el principal enemigo de Quetzalcóatl. El autor lo señala como "capitán y gran guerreador" que causaba crueldades y gran destrucción por donde pasaba. Más adelante, Muñoz Camargo lo nombra como "el diablo Huemac" y deduce, mediante una lectura "etimológica y exegética" su verdadera identidad:

Huemac Tezcatlipoca que quiere decir en la etimología de su nombre El dios espejo o el Dios de la luz y pucah quiere decir Dios negro en lengua de los otomíes Dios Tezcatl en la lengua mexicana quiere decir espejo que compuesto de estos dos verbos en estos dos lenguajes quiere decir Espejo dios negro o Luz Dios y a mi parecer que quisieron llamarle Luzbel como efecto por inducimiento del demonio que los tenía tan subyectos y rendidos pretendiendo ser adorado de estas míseras gentes lo llamaron los mexicanos y tlaxcaltecas Dios de las batallas y a este le atribuían que daba las victorias y así en sus grandes trabajos y peligros invocaban su nombre llamándole Tezcatl y pucas Huemac ${ }^{39}$.

Sin duda, Muñoz Camargo está haciendo referencia a las obras de Bernardino de Sahagún y de Motolinía. Sahagún lo equipara con el dios romano Júpiter y lo asociaba con la guerra y las discordias: "Y andaba por todas partes: lo mismo en el cielo, en la tierra, y en el infierno y temían que cuando andaba por

\footnotetext{
36 Debido a que vivía en los bosques, se creía que era sexualmente agresivo y secuestraban a las mujeres. El "hombre salvaje" tenía el cuerpo cubierto de pelo, tal como se representa en ocasiones el diablo. En el siglo XV el "buen salvaje" personificó la idealización de los habitantes del Nuevo Mundo considerado como la Arcadia en la "Era de oro". LiNK, 1995, pp. 51-52. La primera representación de América y sus habitantes desnudos está en la portada de la versión italiana de Giuliano Dati de la carta de Colón anunciando el descubrimiento, edición realizada en Roma el 18 de junio de 1493. El único ejemplar conocido está en la Biblioteca Colombina de Sevilla.

37 Cuenta Sahagún que en la fiesta de Tóxcatl en honor a Tezcatlipoca y Hutzilopochtli, los sacerdotes llevaban las cabezas emplumadas con plumas blancas de gallina y el rostro pintado de negro. FraY BERnARDino DE SAHAGún, Historia general de las cosas de la Nueva España, libro II, cap. XXIV, México, Imprenta Alejandro Valdés, 1829, p. 108.

38 "Éste [Quetzalcóatl] se tiene por muy averiguado que fue de muy buena disposición blanco y rubio y barbado y bien acondicionado y que estando en Tula le cometieron adulterio los señores de allí, especialmente Tezcatlipoca Huemac que visto su mal término [Quetzalcóatl] se salió de Tula muy enojado y se vino a Cholula [...]”. MuÑoz CAMARGO, ms. Glasgow Hunter 242, f. 85 r.

39 Muñoz CAMArgo, ms. Glasgow Hunter 242, ff. 86v-87r. La identificación de Lucifer con el diablo proviene del Antiguo Testamento (Isaías 14:12). Para los diferentes nombres del diablo ver LiNK, 1995, pp. 19-34.
} 
la tierra movía guerras, enemistades y discordias, de donde resultaban muchas fatigas"40. Por su parte, el padre Motolinía decía que Tezcatlipoca era hermano mayor de Vichilopuchtli (Huitzilopochtli) y ambos "demonios" eran dioses de la guerra "para matar, destruir y sujetar". Además, contaba que su fiesta se llamaba Panquetzaliztli y se celebraba en México y en todas las tierras y provincias sujetas a México los tenían como dioses principales. Más adelante describe cómo durante su fiesta se hacía autosacrificio, rociando la sangre sobre los simulacros como si fuera agua bendita, remedo de la práctica cristiana, y describe en detalle el sacrificio de guerreros ofrecidos a estos dos dioses, como puede verse en la lámina del Templo Mayor del Códice Durán (fig. 5) ${ }^{41}$.

No es por casualidad que, ante la violencia de las ceremonias sacrificiales y por su relación con la guerra, los misioneros, según sus propias creencias, encontraran varios paralelismos entre este dios y Lucifer. Pero, además, porque los naturales consideraban a Tezcatlipoca como el señor de la burla y el engaño. Se decía que era arbitrario, caprichoso y burlón, hacía reír y al mismo tiempo se mofaba de los mortales:

Titlalcaoán, también se llamaba Tezcatlipuca y Moiocoialzin, y Iaotzin, y Necociaautl, y Necaoalpilli. Llamábanle Moiocoialzin, por razón que hacía todo cuanto quería y pensaba, y que ninguno le podía contradecir a lo que hacía, ni en el cielo ni en este mundo, y en dar riqueza a quien quería; y mas decían, que el día que fuese servido de destruir y derribar el cielo, que lo haría, y los vivos se acabarían ${ }^{42}$.

El negro era el color distintivo de Tezcatlipoca, al igual que para el Príncipe de las tinieblas, y su efigie se impregnaba de tizne. Los sacerdotes indígenas llevaban entintado el cuerpo de negro, portaban máscaras confeccionadas con los cráneos de los sacrificados con nariz de pedernal. También a la víctima de sacrificio se le pintaba el cuerpo de negro y se le adherían plumas de gallina en la cabeza "porque ya se le tenía como en lugar del dios". Llama la atención el mancebo, víctima de sacrificio para Tezcatlipoca, en el Códice florentino, cuyo rostro enmascarado con calavera y cabeza emplumada es similar al demonio inferior en el Códice de Glasgow (fig. 6) ${ }^{43}$.

En efecto, Tezcatlipoca, tal como señalaban Sahagún y Motolinía, era nigromante, hechicero y adivino, y decían que mediante sus engaños había matado a muchos toltecas. Realizaba augurios y usaba su espejo para ver el futuro, de allí que también se le llamara "Señor del espejo humeante". Sahagún, asombrado por las "coincidencias" entre algunas prácticas de la religiosidad indígena, decía que Tezcatlipoca recibía especial reverencia: los indígenas solo se arrodillaban ante su efigie, lo llamaban Titlacahua (cuyos esclavos somos) y lo tenían como su mayor dios. Además, el franciscano hacía notar que lo llamaban "Espejo resplandeciente" o donde todo se ve, de manera muy semejante al speculum sine macula, como se nombra a Dios en las Escrituras ${ }^{44}$; ya sea por una malinterpretación de los indígenas de una misteriosa permisión divina para prepararlos para recibir el evangelio, como aducía Sahagún, o mediante el reflejo distorsionado de Satán que intentaba emular a Dios engañando a los indígenas induciéndolos a adorarlo ${ }^{45}$.

40 SAHAGÚN, 1829, libro I, cap. III, p. 2.

41 Motolinía, 1989, pp. 97-98. También Motolinía refería que los indígenas en sus fiestas “comían unos hongos o setas pequeñas que llamaban teunanactlh que quiere decir carne del dios o demonio y que les provocaba visiones y embriaguez". Para Motolinía esto era un acto aberrante de la comunión. MotoliníA, 1966, p. 56. Véase también la referencia de Sahagún del sacrificio en la fiesta de Toxcátl en honor a Tezcatlipoca. SAHAGÚN, 1829, libro II, cap. XXIV, pp. 100-105.

42 SAHagún, 1829, libro III, cap. II, p. 241.

43 Ibidem, libro II, cap. XXIV, pp. 100-103. En la imagen del manuscrito original el mancebo víctima de sacrificio viste piel humana desollada, pero no se menciona en el texto. La piel de víctimas desolladas la usaban los sacerdotes y es parte de la iconografía del dios Xipe.

44 SAHAGÚN, suplemento libro III, p. XXVII.

45 "Pero tales ilusiones tendían a desmoronarse frente al gran número de ceremonias orgiásticas que los frailes no podían ver más que como una forma de seudosacramentalismo impregnado de inversión satánica”. CERVANTES, 1996, p. 30. 


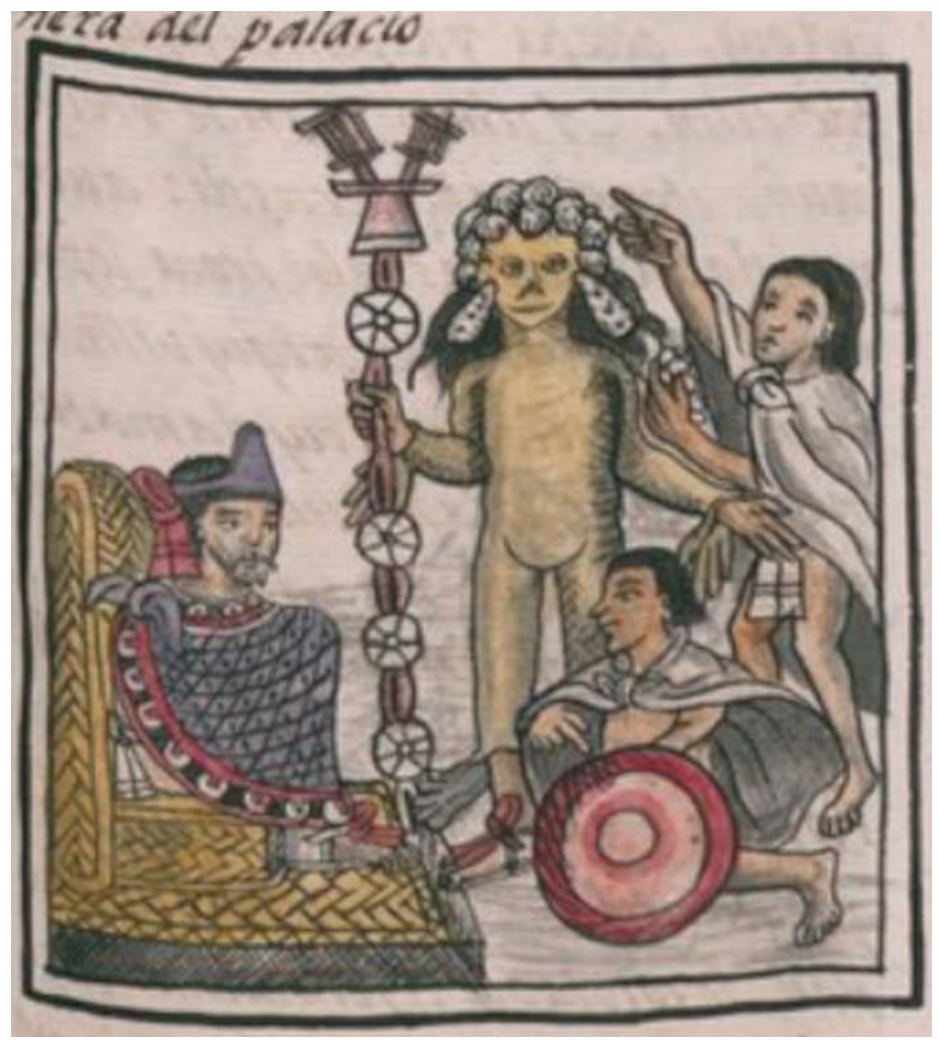

Fig. 6. Víctima de sacrificio ataviado como Tezcatlipoca frente al tlatoani (detalle). Bernardino de Sahagún, Códice florentino o Historia general de las cosas de Nueva España, 1577, libro XI, volumen 3, Biblioteca Laurenciana, Florencia, Ms. Med. Palat. 220, f. 86r (detalle). Imagen digitalizada de la Biblioteca Medicea Laurenciana de Florencia.

Al igual que Lucifer, Tezcatlipoca (y Huitzilopochtli) tenía el pie izquierdo lisiado ("pie arrancado") como precio por su transgresión, y esta carencia estaba relacionada con el inicio del fuego ${ }^{46}$. Según la leyenda de Tamoachán, Tezcatlipoca ebrio asume la forma de un coyote o de un buitre para seducir a la diosa Xochiquetzal (Tlalzoltéotl, Itzpapalotl, Cihuacóatl), quien da luz a Cintéotl-Itztlacoliuhqui o dios del maíz tierno que a la vez representaba a Venus, el lucero de la mañana, paradójicamente identificado con Quetzalcóatl. La venda que lleva en los ojos, a manera de pintura facial (rayas horizontales negras y amarillas), manifiesta la transgresión sexual cometida que precedió al nacimiento de Cintéotl. Así pues, debido a todos estos atributos, para los ojos de los misioneros, Tezcatlipoca era la deidad más parecida a Luzbel, considerado como el señor del pecado, ligado a la nigromancia, embriaguez, lascivia y adulterio ${ }^{47}$.

Ahora bien, ¿cuál es la identidad del otro demonio que alza el vuelo con alas de murciélago? Según decía el fraile Andrés de Olmos, el demonio podía adquirir diferentes formas con la intención de engañar y asustar se transformaba en otras personas y animales:

46 "Él [Lucifer] es cojo por su caída del cielo, sus rodillas están al revés; tiene una cara adicional en el abdomen, en las rodillas o en las nalgas. Es ciego, tiene cuernos y cola; no tiene fosas nasales o solamente una, no tiene cejas; tiene ojos de hechicero que brillan [...]". Burton Russell, 1988, p. 68. La traducción es mía. Guilhem Olivier, Tezcatlipoca: Burlas y metamorfosis de un dios azteca, México, Fondo de Cultura Económica-CONACULTA-UNAM, 2004, pp. 39-47 y 473.

47 Olivier, 2004, pp. 217 y 481. 
Todos deben saber que el Diablo ciertamente puede tomar muchas formas y, cuando lo desee, formar nuevas criaturas; a veces para engañar a alguien, a veces para atacarlo, lo espanta, lo aterroriza y lo asusta. Y nadie puede dudarlo, nadie puede ignorarlo, ya que asumió el aspecto de otro varias veces, como vemos escrito en las Vidas de los Padres de Egipto. El Diablo puede hacer lo mismo con sus hechiceros, llevándolos a tomar otra apariencia, y tal vez incluso mejorarlo sin que la sustancia varíe y nada en la imagen del hechicero desaparezca, se transforma ${ }^{48}$.

En la mentalidad medieval casualmente uno de los poderes que tenía Lucifer era la capacidad de transformarse en distintos animales, monstruos o personas ${ }^{49}$. También Tezcatlipoca podía adoptar la apariencia generalmente de animales nocturnos como el jaguar, buitre, pequeño zorro o coyote. El coyote era el doble o nahualli preferido del "Señor del espejo humeante" que tenía la función principal de ser el mensajero de los dioses. Pero, a la vez, carecía de forma. Según los informantes de Sahagún, Tezcatlipoca era invisible e intocable como la noche o como el viento, y tenía el don de la ubicuidad ${ }^{50}$.

Sin embargo, dentro de la complejidad del panteón nahua, Quetzalcóatl, dios antagónico y complementario de Tezcatlipoca, tenía como su gemelo o nahual al perro Xólotl. Es posible que dentro de este traslado iconotrópico el demonio con hocico de cánido del manuscrito de Glasgow fuera, paradójicamente, el gemelo de Quetzalcóatl. Me parece sugerente que pueda tratarse de este dios convertido en perro y que viajó al inframundo-infierno para recobrar los huesos de la generación previa destruida por los dioses y así dar inicio a una nueva humanidad, es decir, a una nueva era ${ }^{51}$. Las alas de murciélago, además de ser distintivo de los demonios voladores, aluden al dios murciélago Tzinacan, entidad del inframundo y relacionado con Quetzalcoátl y con la trasgresión de Tezcatlipoca en un mito sobre la fertilidad y la muerte:

Tzinacan nace del semen y la sangre derramados por Quetzalcóatl en uno de sus autosacrificios. Es enviado entonces a que muerda el órgano genital de la diosa Xochiquétzal, y una vez que se lo arranca, lo entrega a los dioses, quienes lo lavan, y de esa agua nacen flores olorosas. Luego lo llevan al inframundo y ahí Mictlantecuhtli, señor de los muertos, lo vuelve a lavar y de esa agua nace el cempoalxóchitl, flor de los muertos ${ }^{52}$.

\section{La imposición de la cruz. Los dioses, ángeles caídos}

En el dibujo del folio 239v del Códice de Glasgow se muestra el momento en que los primeros misioneros impusieron la cruz para santificar el espacio idolátrico en las tierras tlaxcaltecas como señal de que esos territorios ya habían sido ganados para Cristo (fig. 7). Los doce frailes franciscanos, vistiendo sus hábitos con sus rosarios atados a la cintura, de hinojos y aludiendo a los doce apóstoles, rinden culto a la cruz y expresando así la idea franciscana de renovación del cristianismo y de interpretar su labor misionera como una contribución especial para la realización de la historia providencial en las regiones de ultramar ${ }^{53}$. Una composi-

48 Andrés de Olmos, Tratado de hechicerías y sortilegios de Andrés de Olmos (traducción y comentarios de George Baudot), cap. VII "De como en diversas figuras pueden aparecer los ministros del demonio", México, Misión Arqueológica y Etnológica Francesa en México, 1979, p. 122. La traducción del francés al castellano es mía.

49 Burton Russell, 1988, p. 49.

50 Olivier, 2004, pp. 69-70, 200, 244 y 255.

51 Bernardino de Sahagún cuenta que los viajeros a veces en su camino encontraban un coyote enroscado por una serpiente, lo que indica una estrecha asociación simbólica entre Tezcatlipoca (coyote) y Quetzalcóatl (serpiente). FRAY BERNARDINO DE Sahagún, Fauna de Nueva España, cap. I "De las Bestias Fieras”, México, Fondo de Cultura Económica, 2013, p. 7.

52 María Teresa MuÑoz Espinosa, "El culto al dios Murciélago en mesoamérica", Arqueología Mexicana, n 80 (2006), pp. 17-23. Llama la atención que, según los informantes de Sahagún, el excremento de murciélago (njctzinacancujtlavia) se usaba para pegar las piezas del espejo de Tezcatlipoca. OLIVIER, 2004, p. 430.

53 Sergio BоттA, "Una negación teológica política en la Nueva España: Reflexiones sobre la labor franciscana (siglo XVI)", en M.I. Campos y M de G. Goenaga (coords.), La cruz de maíz. Política, religión e identidad en México: entre la crisis colonial y la crisis de la modernidad, México, INAH-CONACULTA-CONACYT, 2011, p. 40. 
ción semejante está en la pintura mural realizada en el siglo XVI en el convento franciscano de Huejotzingo en el estado de Puebla, a poca distancia de la ciudad de Tlaxcala, pero en ella aparecen escritos los nombres de cada uno de los religiosos (fig. 8). En efecto, ocho meses después de la derrota de la ciudad tenochca en la bula Exponi Nobis fecisti, el papa Adrián VI concedió privilegios extraordinarios a Hernán Cortés para enviar a los primeros misioneros de la orden seráfica a las tierras recién conquistadas. Cortés recibió en 1524 a los primeros doce franciscanos que iniciaron el proceso de cristianización ${ }^{54}$.

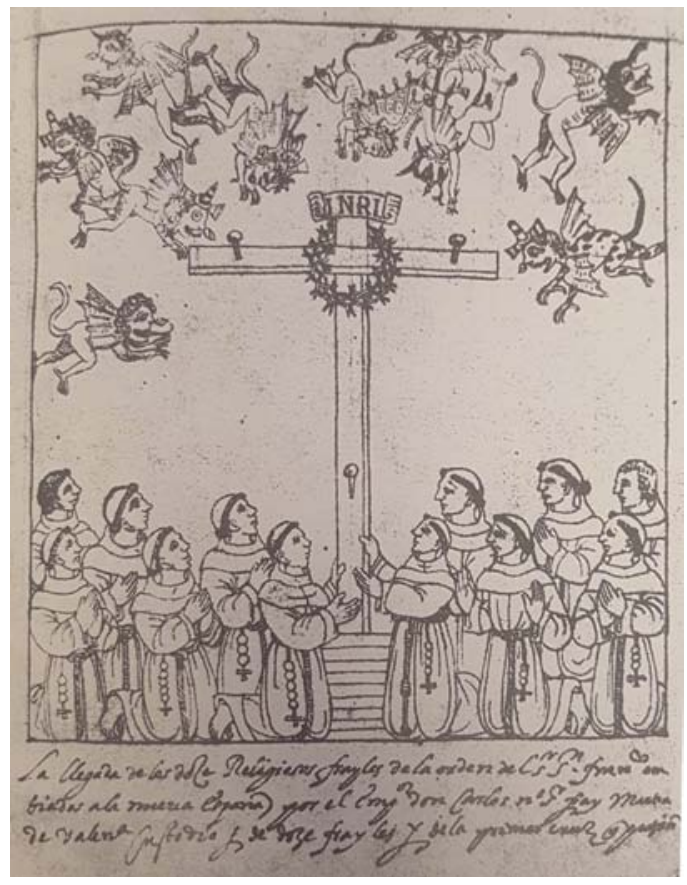

Fig. 7. Exaltación de la cruz. Diego Muñoz Camargo, Descripción de Tlaxcala, ca. 1583, Biblioteca de la Universidad de Glasgow, Ms. Glasgow Hunter 242, f. 239v, dibujo a tinta, 21 x29 cm. Fotografía de la edición facsimilar: Diego Muñoz Camargo, Descripción de la Ciudad y Provincia de Tlaxcala de las Indias y del Mar Océano para el buen gobierno y ennoblecimiento dellas, México, Instituto de Investigaciones Filológicas-UNAM, 1981.

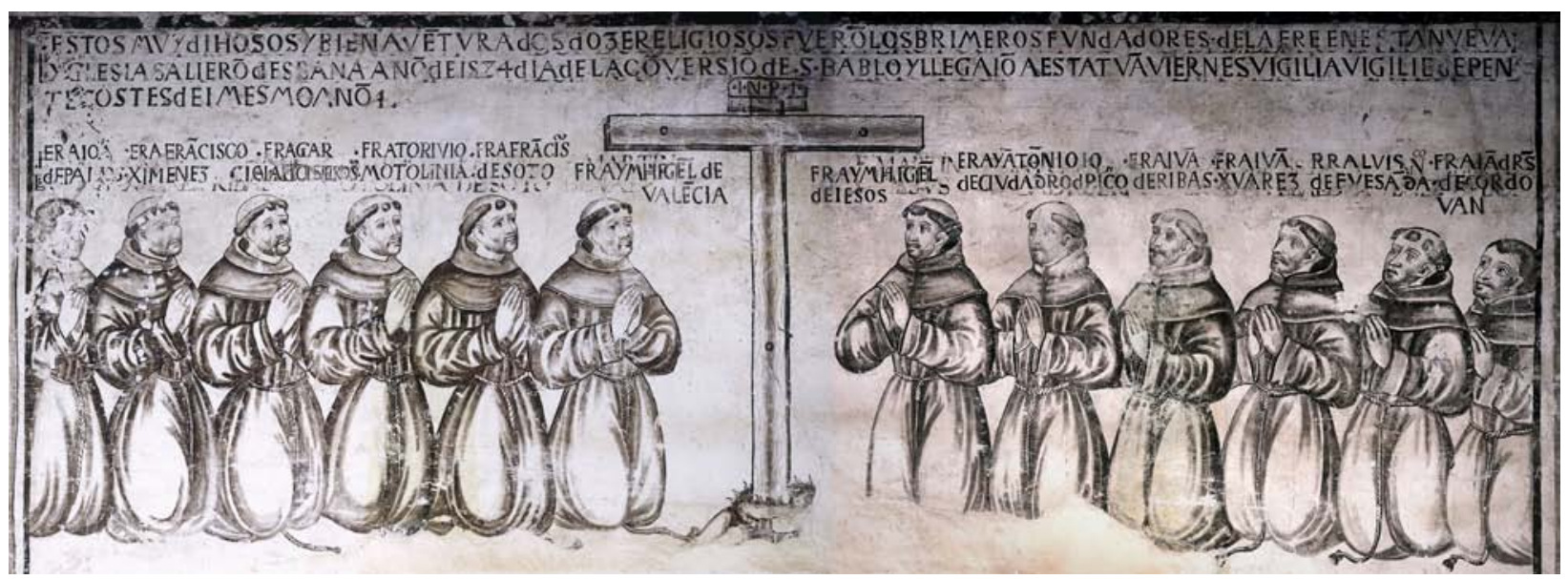

Fig. 8. Anónimo, Los doce franciscanos, pintura al fresco, grisalla, Sala de profundis, Convento de San Miguel Arcángel, Huejotzingo, Puebla (México). Fotografia de Eumelia Hernández Vázquez, 2004. Archivo Fotográfico “Manuel Toussaint”, IIE, UNAM.

${ }^{54}$ En el dibujo se representan a fray Martín de Valencia, Francisco de Soto, Martín de la Coruña, Juan Juárez, Antonio de Ciudad Rodrigo, Toribio de Benavente Motolinía, García de Cisneros, Luis de Fuensalida, Juan de Ribas, Francisco Jiménez, Andrés de Córdoba y Juan de Palos. Viviana DíAz BALSERA, The Pyramid Under the Cross: Franciscan Discourses of Evangelization and the Nahua Christian Subject in Sixteenth Century Mexico, Tucson, Arizona University Press, 2005 , p. 4. 
Sin embargo, en esta imagen del Códice de Glasgow encuentro un intrincado discurso simbólico que merece desvelar. Se sabe que los doce primeros franciscanos que llegaron a tierras americanas evocaban a los doce apóstoles que se dispersaron para llevar la Buena Nueva a regiones lejanas después de la muerte de Jesús. Esta composición pertenece al tropo iconográfico tardomedieval de la exaltación de la santa cruz. En el centro de la composición aparece el objeto de martirio del Salvador con la inscripción infamante, con las letras iniciales: Iesus Nazarenus Rex Iudaeorum. En el centro está dispuesta la corona de espinas y en sus tres extremos se ven los clavos. Cabe hacer notar que en este caso no aparece la imagen del cuerpo de Cristo. Por lo tanto, la cruz, revestida con estos elementos pasionarios está actuando más bien como símbolo y no como vera efigie del Redentor. En mi opinión, esto tiene el propósito específico de dejar en claro que se evitó en esta composición cualquier posible confusión entre representación y prototipo. La devoción de las imágenes fue una práctica muy criticada por los protestantes, algunos incluso la tachaban de idolatría, tal como lo refiere Sahagún ${ }^{55}$. Recordemos que en el siglo XVI surgieron intensos debates sobre el uso de las imágenes de devoción en la evangelización del Nuevo Mundo por temor a conducir a los indígenas a generar actos de idolatría sustituyendo los simulacros de sus dioses con las imágenes cristianas.

En la parte superior, alrededor de la cruz, se observan varias criaturas voladoras. La disposición de los personajes del dibujo del Códice de Glasgow, guardando las distancias, recuerda a algunos elementos compositivos del fresco de la Crucifixión de Giotto (1267-1337) realizado alrededor de 1320 en la Basílica Inferior de Asís, sobre todo la relación de la cruz con los ángeles volando y los franciscanos arrodillados: entre ellos, en primer plano, se distingue por su halo a san Francisco y a san Buenaventura (fig. 9). En la lámina del Códice de Glasgow, en lugar de los ocho seres angélicos en actitud de duelo que rodean la cruz en la pintura de la basílica, mediante una inversión de sentido, se observan diez demonios con alas de murciélago, algunos inclusive tienen posturas semejantes a los ángeles de Giotto. Se sabe que la iconografía del diablo en la tradición medieval se concebía como la "anti-forma" de los ángeles o un remedo contrahecho y deforme de los mensajeros de Dios. Estas criaturas grotescas son ángeles caídos que revolotean desorientadas alrededor del máximo signo cristiano provisto de las arma Christi, que actúa como escudo protector contra el Enemigo de Dios. Me pregunto si mediante esta semejanza existió la intención de hacer un "traslado simbólico" de san Francisco y del locus sagrado más importante para los Hermanos Menores, dado que allí están las reliquias del santo fundador de la orden ${ }^{56}$.

Al igual que los ángeles en la pintura de la Basílica de Asís, estos demonios son espíritus incorpóreos porque en su origen también fueron ángeles. Tienen algunos elementos claramente diabólicos de la tradición tardomedieval: alas de murciélago, lenguas viperinas, garras, cola y cuernos. Mediante una ingeniosa simbiosis visual, también se distinguen atributos totalmente ajenos a la figura del diablo ${ }^{57}$. Así pues, aquí estos secuaces

\footnotetext{
55 "El que entrase en las iglesias católicas sin entender su religión y lengua, pensaría que tenemos tantos dioses como imágenes y según las diferencias de nombres, figuras y advocaciones que damos a Cristo y su Madre, los multiplicaría a millares, y no dudaría atribuir divinidad a los santos, viéndolos sobre los altares dedicados templos a su nombre, dando a ellos patronazgos de ciudades y villas, protección a cada uno contra ciertas enfermedades, para ciertas cosas, y a favor de ciertos gremios, con la circunstancia de que en tal parte su imagen es más milagrosa que en otra. Con todo lo cual nos daría por idólatras extravagantes y desatinados, y así lo hacen lo protestantes". SAHAGún, 1829, suplemento libro III, pp. XXVI-XXVII.

$56 \mathrm{El}$ tema de la crucifixión con ángeles fue muy recurrente en siglo XIV y perduró hasta el siglo XVI. Giotto pintó alrededor de 1310 una composición muy semejante en la Capilla de los Scrovegni en Padua, pero en esta versión hay diez ángeles y no aparecen los cinco franciscanos. Además, está la pintura sobre tabla de la Crucifixión, también realizada por Giotto entre 1315 y 1320 , actualmente en el Museo de Bellas Artes de Estrasburgo. Sandrina BAndera Bistoletti, Giotto: catálogo completo, Madrid, Akal, 1992, pp. 110-119. En la pintura sobre tabla realizada en la segunda mitad del siglo XV por Andreas de Pavias, en el Museo Alexandros Soutzos de Atenas, en el lado derecho, revoloteando arriba de uno de los ladrones crucificados, está Satán, caracterizado como un ser negro con cuernos, garras y alas de murciélago. De manera similar, en la pintura de Josse Lieferinxe, realizada cerca de 1500, en el Museo del Louvre, se mira en el lado derecho la lucha entre las huestes angélicas, comandadas por san Miguel, contra Luzbel, que cae desde las alturas y es acompañado por un par de demonios (ángeles rebeldes). Llama la atención que uno de estos demonios tiene un pie en forma de sierpe que coincide con algunas representaciones mesoamericanas del dios Tezcatlipoca ("pie arrancado").

57 Me parece desconcertante que Fernando Cervantes señale solamente los atributos característicos del diablo europeo en esta representación y omita por completo la iconografía propia de las deidades indígenas. CERVANTES, 1996, p. 28.
} 


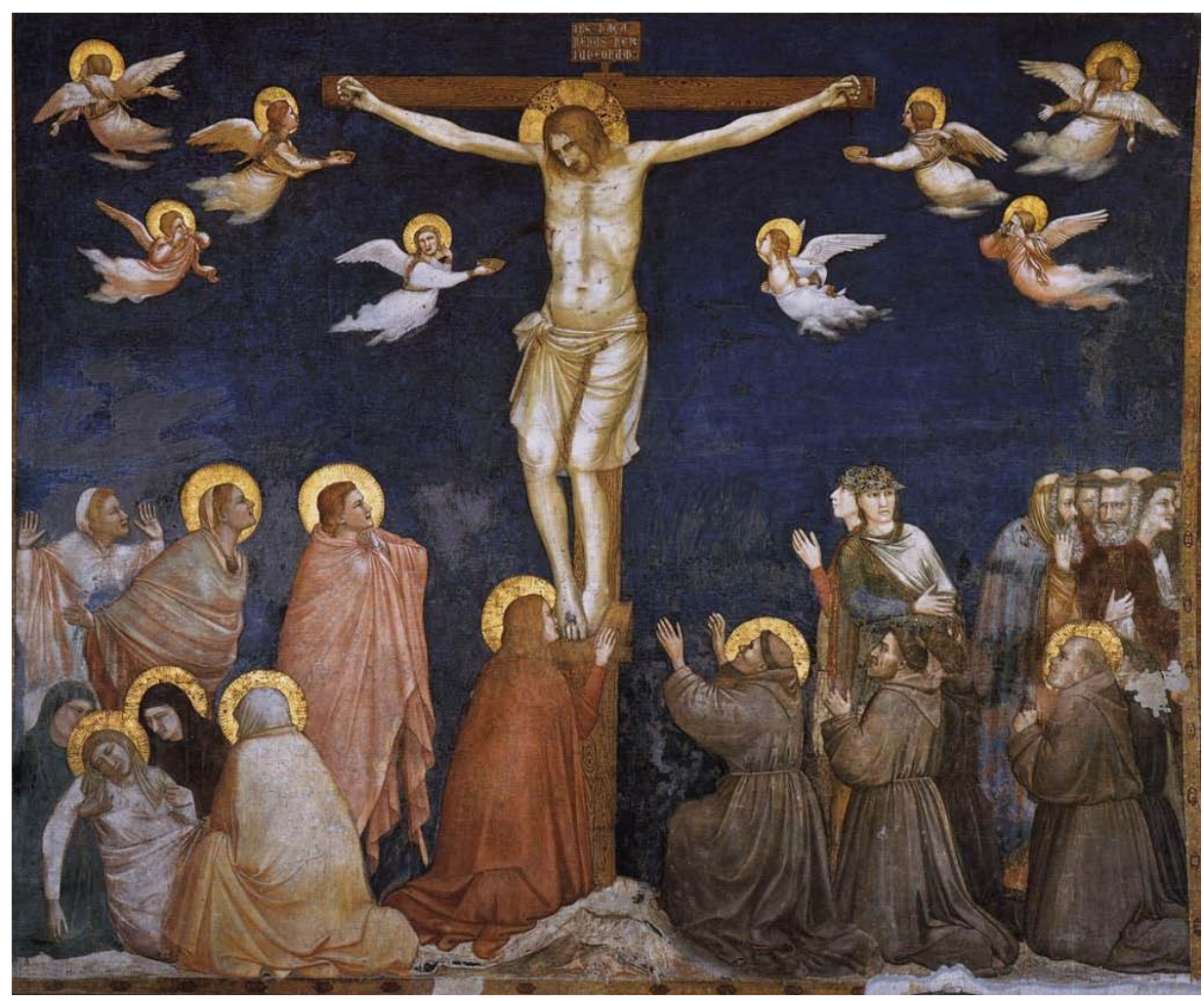

Fig. 9. Giotto, Crucifixión, Basílica Inferior de Asís (Italia), ca. 1320. Fotografía: Sandrina Bandera Bistoletti, Giotto: catálogo completo, Madrid, Akal, 1992.

de Satán se han tornado en seres híbridos que comparten la iconografía de los demonios europeos y de los dioses mesoamericanos; en otras palabras, están en situación de nepantla. Son seres liminares, en formación, todavía inacabados; producto, más bien, de asimilaciones y reacomodos ante una nueva realidad.

En el lado izquierdo cuatro demonios portan máscaras de cráneo con nariz de pedernal. Dos de ellos ostentan tocados cónicos con moños pintados con rayas, solamente uno tiene cuernos. Cabe agregar que las máscaras de cráneo son similares a la que porta el demonio del dibujo de La destrucción del templo idolátrico ${ }^{58}$. Entre estos seres, destaca un demonio por demás perturbador: es de mayor tamaño, tiene rostro humano y parece caer en picada hacia la cruz. Muestra pintura facial con franjas horizontales, lleva orejeras y bezote, porta tocado con borla de algodón y plumas largas de garza (aztaxelli). Estos atributos pertenecen al dios Tezcatlipoca, su iconografía remite a la representación del mismo dios en el Códice Tudela (fig. 3). Este personaje está relacionado con sus otros cuatro acompañantes que portan máscara de cráneo porque son sus demonios-sacerdotes. Además, el cráneo decapitado alude al signo calendárico de este importante dios, "uno muerte" (ce miquiztli), asociado con la luna, la fertilidad y posiblemente con los adivinos. Según los informantes de Sahagún, Tezcatlipoca se consideraba el dios-sacerdote, confesor de los penitentes y con poderes oraculares, porque por medio de su espejo de obsidiana adivinaba el futuro. Engañaba y se burlaba de la gente porque cambiaba los destinos, por eso también se le nombraba Neoc Yáotl o "Enemigo de los dos lados"; también ocasionaba pestes y enfermedades por lo que se le llamaba "Viento nocturno" (Yahualli Ehécatl)".

58 Estas máscaras provenían de individuos sacrificados. Se han encontrado algunas de ellas colocadas en ofrendas, por ejemplo, en el Templo Mayor en la ciudad de México.

59 Olivier, 2004, pp. 73-89. 
En la parte central superior del dibujo hay otro personaje en dirección a la cruz, también con rostro humano, pero de menor tamaño que Tezcatlipoca. Luce orejeras y la diadema de turquesa xiuhuitzoli, que era un atributo del dios viejo del fuego Huehuetéotl-Xiutecuhtli, tal como se muestra en el Códice Telleriano Remensis. La diadema de turquesa representaba en tiempos prehispánicos a la xiuhcóatl o serpiente de fuego que dio inicio a la creación del cosmos, por consiguiente, también era el tocado del dios Tonacatecuhtli, creador del universo y asociado con la fertilidad. Además, era el atributo distintivo del máximo gobernante, huey tlatoani o tlacatecuhtli. A este propósito Diego Muñoz Camargo detalló en su manuscrito: "Se ponían tiaras a manera de mitras que servían de coronas y que algunos de sus ídolos los ponen pintados con estas coronas y altos reyes que tienen memorados en sus antigüedades" ${ }^{60}$. ¿Acaso este personaje también representa a Moctezuma, señor de Tenochtitlan, y su caída representa la derrota de su reino idolátrico?

Hay otra posibilidad: junto al marco superior está un ser más pequeño de espaldas, tiene un rostro monstruoso parecido a un lagarto con fauces pronunciadas. Es posible que sea el dios del viento Ehécatl porque trae uno de sus principales atributos, la máscara bucal. De ser así, aquí Quetzalcóatl podría estar representado desdoblado bajo sus dos naturalezas: como huey tlatoani de la ciudad tolteca de Tula, en su forma humana, tal como menciona Muñoz Camargo, coronado por la diadema de turquesa. A la vez, con su versión divinizada Ehécatl, dios tolteca del viento.

Así entonces, en este dibujo estarían los dos dioses-demonios principales para Sahagún y para Muñoz Camargo, "hermanos-adversarios": Tezcatlipoca y Quetzalcóatl, el dios negro y el dios blanco, como si se tratara de un espejo y su reflejo a la inversa. Según se narra en la Historia de los mexicanos por sus pinturas, Tezcatlipoca fue el primer Sol durante el cual vivieron los gigantes y después de trece veces cincuenta y dos años, Quetzalcóatl lo derribó con su bastón para ponerse en su lugar, como el nuevo Sol ${ }^{60}$. Muñoz Camargo lo señalaba como la antítesis del espantable Tezcatlipoca: "Éste [Quetzalcóatl] se tiene por muy averiguado que fue de muy buena disposición blanco y rubio y barbado y bien acondicionado y que estando en Tula le cometieron adulterio los señores de allí, especialmente Tezcatlipoca Huemac que visto su mal término [Quetzalcóatl] se salió de Tula muy enojado y se vino a Cholula" ${ }^{62}$. Esta descripción de las características europeas del dios blanco contribuyó a la construcción de la leyenda novohispana sobre la venida de santo Tomás a tierras tlaxcaltecas, antes de la llegada de los conquistadores ${ }^{63}$.

Debajo del dios del Viento, de mayor tamaño desciende un personaje con aspecto más cercano al diablo europeo, destacan sus cuernos y tiene el pie izquierdo visiblemente flexionado. Sin embargo, porta máscara de cráneo con nariz de pedernal y muestra ostensiblemente lengua viperina. Por estas características lo identifico como un híbrido entre Luzbel y Mictlantecuhtli "Señor de la Muerte", gobernante del inframundo. Llama la atención que está en una posición semejante a Tezcatlipoca, lo que acentúa la simetría en la composición. A manera de reflejo, el artista quiso indicar las dos naturalezas maléficas del demonio enmascarado por la figura de los dioses indígenas: Tezcatlipoca-hechicero y Mictlantecuhtli-muerte.

Por un lado, en la tradición mesoamericana Tezcatlipoca con frecuencia se representa en lugar del dios de la muerte, del cual toma su atavío característico, como se observa en algunos códices precolombinos ${ }^{64}$.

\footnotetext{
60 Muñoz CAmargo, ms. Glasgow Hunter 242, f. 83v. Llama la atención que Muñoz Camargo las llama "mitras” porque apunta a la simulación perversa de la figura del papa dentro del embuste del diablo.

61 Olivier, p. 173. También ver Michael Graulich, Mitos y rituales del México Antiguo, Madrid, Istmo, 1990.

62 Muñoz Camargo, ms. Glasgow Hunter 242, f. 85r.

63 Para el siglo XVI en el discurso barroco novohispano Quetzalcóatl se identificaba con santo Tomás. Jaime CUADRIELLO, Las glorias de la República de Tlaxcala o la conciencia como imagen sublime, México, Instituto de Investigaciones Estéticas, UNAM, MUNAL, 2004, pp. 390-391.

${ }^{64}$ Con frecuencia en las culturas mesoamericanas en una misma entidad se aúnan características de diferentes dioses que indican la idea de que en el cosmos se combinan fuerzas contrarias y complementarias, por ejemplo, en el Códice Borgia o el Códice Laud. Sobre cosmovisión en el Altiplano Central de México ver Alfredo López Austin, Cuerpo humano e ideología. Las concepciones de los antiguos nahuas, México, Instituto de Investigaciones Antropológicas-UNAM, 1989, vol. 1, pp. 55-97.
} 
Los nahuas atribuían a Tezcatlipoca la capacidad de reflejar la verdad en su espejo de obsidiana. Por ello, uno de sus nombres era Texcatlanextia, "Espejo que hace aparecer las cosas", y que expresa la facultad del dios de revelar, mediante su artefacto de obsidiana, los pecados y los destinos de los hombres ${ }^{65}$. Según las palabras de Sahagún, Tezcatlipoca transformado como un joven le muestra el espejo a Quetzalcóatl, quien después de cometer incesto al estar ebrio, vio reflejado en el espejo su pecado: "A la vista de su rostro abotagado y de sus ojos hundidos, Quetzalcóatl se asustó y exclamó que con seguridad sus súbditos huirían si lo veían". Según esta leyenda que retoma Muñoz Camargo, la ruina de Tula devino del pecado cometido por su rey-dios Quetzalcóatl al ser inducido a transgredir y quedar al descubierto por su adversario Tezcatlipoca ${ }^{66}$, quien, a los ojos de Sahagún, tentaba a los hombres de manera muy similar a la del diablo.

Por otro lado, en la iconografía europea Luzbel se asocia con otras figuras temibles como la muerte y el infierno, tal como se dice en el Apocalipsis (Ap 20). Después del siglo XI el diablo y la muerte se representan como dos entidades independientes, pero con frecuencia uno acompaña a la otra, o bien el rostro del diablo es sustituido por un cráneo para mantener la asociación. De esta manera, se alude a la muerte como consecuencia de la instigación del diablo que llevó a la expulsión del Paraíso a Adán y Eva. Por ello, Luzbel también suele tener características viperinas o se representa en forma de serpiente ${ }^{67}$. Así pues, en este dibujo, mediante el artilugio de su propio espejo, Tezcatlipoca aparece al descubierto con su verdadera identidad: Luzbel-Muerte. Nótese que entre ambos personajes se yergue el stipes de la cruz como el vehículo simbólico de esa revelación, es decir, como el espejo de la verdad. A la vez, Luzbel-Muerte forma una triada con Quetzalcóatl y Ehécatl, ¿acaso una inversión diabólica de la Santísima Trinidad?

En el lado derecho, el demonio ubicado en la esquina superior tiene rostro de cánido, puede ser el coyote viejo (huehuecóyotl), relacionado con la luna y la fertilidad, forma que adquirió Tezcalipoca al seducir a Xochiquetzal. Debajo de él está otro dios-demonio con piel moteada de felino, es un jaguar que también era otra manifestación de Tezcatlipoca. Recordemos que cuando Tezcatlipoca era Sol y Quetzalcóatl lo derribó, el "Señor del espejo humeante" se transformó en jaguar. Este felino representaba al Sol nocturno que viajaba al mundo de los muertos al caer la noche para renacer al otro día transformado en águila surcando la bóveda celeste. Asimismo, en la cosmovisión mesoamericana, el jaguar, al igual que el águila, era el mensajero que llevaba los corazones de los sacrificados a los dioses.

También puede ser que el demonio-cánido sea Xólotl, manifestación nocturna de Quetzalcóatl, como en el dibujo anterior. Recordemos que el dios-perro conducía a los muertos al Mictlán o inframundo, lugar que los misioneros identificaron con el infierno. Llama la atención que ambas criaturas, el perro y el jaguar, llevan direcciones distintas y parece que están volando en círculo, tal vez, con el propósito de indicar el movimiento continuo del tiempo y la alternancia de las eras o "Soles" regidas por Tezcatlipoca y Quetzalcóatl, según la cosmovisión mesoamericana. Cabe señalar que, en la cosmovisión prehispánica, la alternancia de los "Soles" no era más que otro juego de espejos, al igual que la vida y la muerte.

\section{La quema de los ídolos: simulacros o ixiptlah}

En el folio $242 \mathrm{v}$, en una composición simétrica, se observa a dos frailes franciscanos con teas encendidas, ayudados por un par de jóvenes indígenas cristianizados que les acercan leña para quemar la parafernalia "idolátrica". En un amasijo confuso y entre las llamas, se ven máscaras, huesos, cráneos, rostros, escudos y banderolas. De la gran pira penden las banderas pamitl que se usaban para marcar al sacrificado o se ponían sobre los bultos mortuorios en las ceremonias funerarias. Esto indica el fin de los antiguos

\footnotetext{
65 OLIVIER, 2004, pp. 150 y 459.

66 Ibidem, p. 457.

67 Burton Russell, 1988, pp. 211-212.
} 
dioses. En esta lámina, el diablo ya no está presente como espíritu incorpóreo. Ahora, en su lugar, están solamente los simulacros de los dioses nahuas condenados a la destrucción del fuego purificador, arden como un Sol en agonía (fig. 10) ${ }^{68}$.

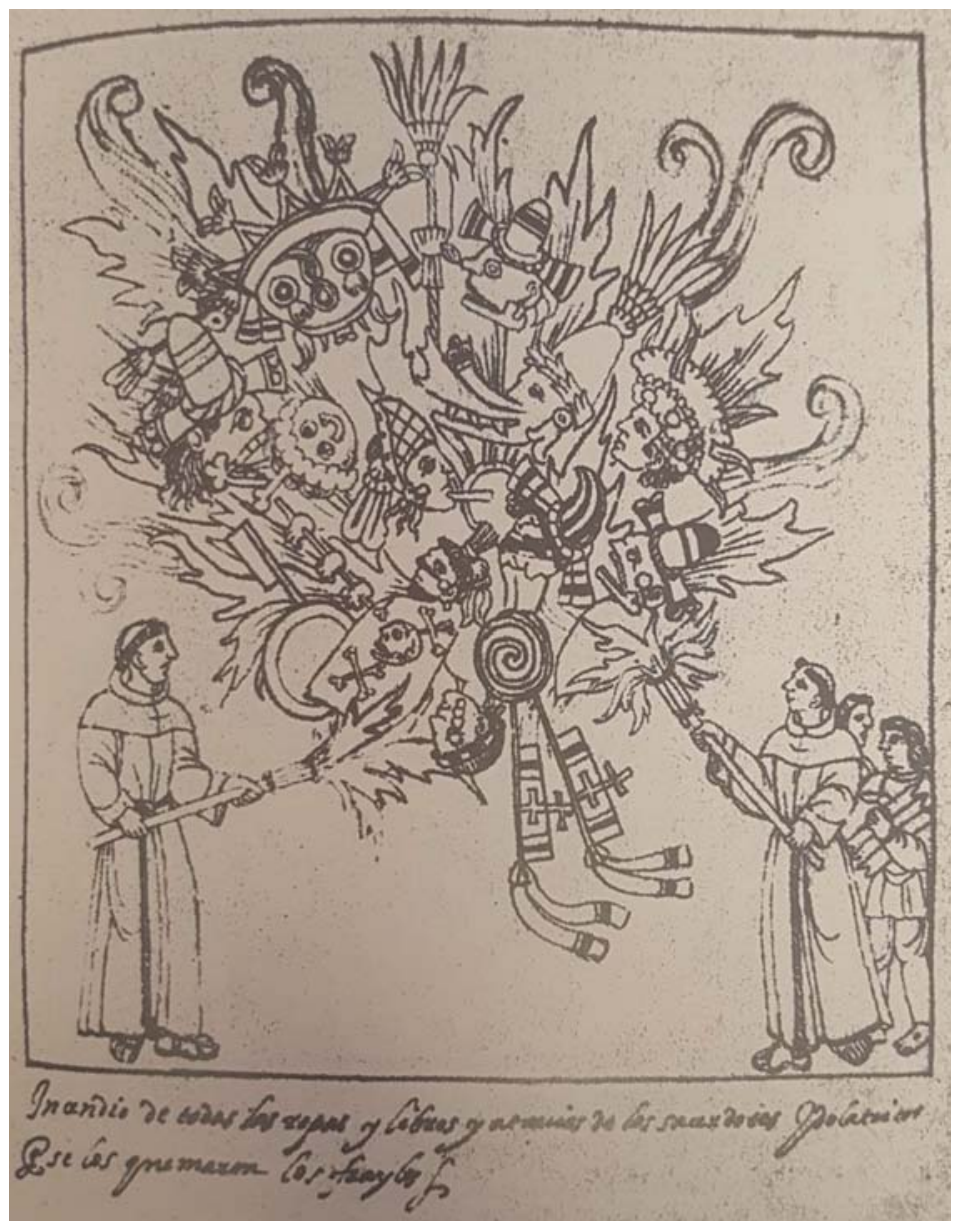

Fig. 10. Destrucción de los ídolos. Diego Muñoz Camargo, Descripción de Tlaxcala, ca. 1583, Biblioteca de la Universidad de Glasgow, Ms. Glasgow Hunter 242, f. 242v, dibujo a tinta, $21 \times 29$ cm. Fotografía de la edición facsimilar: Diego Muñoz Camargo, Descripción de la Ciudad y Provincia de Tlaxcala de las Indias y del Mar Océano para el buen gobierno y ennoblecimiento dellas, México, Instituto de Investigaciones Filológicas-UNAM, 1981

En la parte superior se distingue la gran máscara del dios Tláloc. A su lado derecho vemos nuevamente al señor de la muerte Mictlantecuhtli y debajo se observan corazones ensartados, tal como los identificaron iconográficamente Brotherston y Gallegos, claramente alusivos al sacrificio porque dentro de la cosmovisión mesoamericana el corazón o yallotl se consideraba el centro vital y energético donde residía la consciencia ${ }^{69}$. En el lado derecho está el dios del viento Ehécatl-Quetzalcóatl con tocado cónico adornado de plumas de quet-

\footnotetext{
${ }^{68}$ Se creía que la señal de la cruz o la presencia de los santos, al igual que el fuego, alejaban a los demonios. BuRTON RUSSELL, 1988 , p. 51.

69 Brotherston y Gallegos, 1990, p. 133.
} 
zal y máscara bucal. A su lado, se halla el dios solar Tonatiuh, para nuestra sorpresa, se representa con perfil "a la romana", inclusive, con el cabello en rizos. ¿Estará intencionalmente relacionado con el simulacro del dios Apolo, tal como lo identificó Sahagún? Esto no es de extrañar porque en el Códice florentino los dioses nuahuas son comparados con las deidades de la Antigüedad Clásica, otra curiosidad iconotrópica.

Debajo de la deidad solar y casi en el centro, se ve al dios tutelar tlaxcalteca Camaxtli con tocado cónico a rayas. También puede ser el dios Iztlacoliuhqui o el Señor del cuchillo torcido de obsidiana, deidad que representa el sacrificio y el frío, como otra manifestación de Venus. En la parte inferior, con el rostro invertido, se halla el dios de la caza Mixcóatl, lleva una banda en la frente y pintura facial en forma de círculos. Camaxtli y Mixcóatl estaban íntimamente relacionados, inclusive en ocasiones se los representaban como una sola deidad, tal como aparece en el Códice Tudela y en el Códice Terelliano-Remensis ${ }^{70}$.

En el centro de la pira, se distingue otra vez el dios Huehuetéotl-Xiuhtecuhtli-Tonacatecuhtli (o bien, Quetzalcóatl como tlataoni de Tula) portando la diadema de turquesa. Debajo de él, está Tezcatlipoca con el cabello recogido en un nudo ("cabello de cepillo") y luce borla de algodón con plumas de garza (aztaxelli). Nótese que en este dibujo aparece el dios del espejo cubierto por una manta (tilmatl) ornamentada con calaveras y huesos cruzados, lo que indica que se trata más bien de su efigie. El dominico fray Diego Durán (1537-1588) describía la escultura de Tezcatlipoca del templo de México, tallada en madera y pintada de negro. Además añadía que "[estaba] sentado en asentadora de palo a su modo vestido de una manta colorada toda labrada de claveras de muertos y huesos cruzados"71. En el Códice Tudela se señala que era la "manta del demonio" y la usaban para cubrir la caja de reliquias de los sacrificados a Tezcatlipoca. Este tejido se representa en las pinturas en dos de sus folios (ff. 50r y 76r).

A diferencia de la lámina anterior, aquí ya no aparecen los espíritus del mal incorpóreos, solamente sus simulacros vacíos de las "fuerzas activas" diabólicas. Estamos ante la destrucción de los ídolos, entendidos como receptáculos materiales en los que se ocultaba el demonio, a manera de disfraz, pero desprovistos de la presencia diabólica. Sin embargo, llama la atención que aquí los rostros de los dioses se representan con un notorio carácter antropomorfo y con peculiar expresividad (excepto la máscara de Tláloc y las máscarascráneo) que obedece a la tradición europea del dibujo. No es del todo claro si son efigies o son los propios dioses en persona condenados a la hoguera. En este dibujo parece haber, tal vez de manera intencional, una ambigüedad hipostática entre imagen y prototipo. En la cosmovisión nahua se creía que en las efigies de los dioses estaban contenidas sus fuerzas anímicas. El término ixiptlah se ha traducido como "imagen", "delegado", "reemplazo", "sustituto", "personaje" o "representante". Alfredo López Austin identifica a la partícula del náhuatl xip como "piel", "cáscara" o "cobertura". Pero también lo relaciona con nahualli (el doble), cuando una entidad se posesionaba o se transformaba en otro ser o persona adoptando su identidad. ¿Se podría suponer que los simulacros representados en este dibujo tuvieran la intención de ser interpretados como ixiptlah para los ojos indígenas? En el margen inferior del dibujo, a manera de explicación, se lee: "Incendio de todas las ropas y libros y atavíos de los sacerdotes idolátricos que se los quemaron los frailes". Esta aseveración nos indica que estos objetos se consideraban como ixiptlah en las prácticas religiosas indígenas. Me pregunto si, a la vez, la representación de estos objetos en el dibujo también tendría la misma condición de ixiptlah bajo la mirada indígena, inadvertida para los europeos, tal como lo propuso Diana Magaloni para el Códice florentino. En el dibujo del Códice de Glasgow se destacan principalmente las caras de los dioses y no aparecen sus cuerpos. Diana Magaloni menciona que ixiptlah contiene el morfema ixt [li]

\footnotetext{
70 Los rostros de Camaxtli y Mixcóatl son muy parecidos a los representados en el Códice Tovar.

71 Diego Durán, Historia de las indias y Nueva España del mar océano, México, Imprenta de J.M. Andrade y F. Escalante, 1867, p. 106. Asimismo, Sahagún menciona esta manta labrada con huesos humanos de un desmembrado. SAHAGÚN, 1829, libro II, cap. XXIV, pp. 104-105. También se cubrían con un tejido similar los confites que se preparaban como ofrenda para el dios Tezcatlipoca. $\mathrm{Y}$ un tejido con este patrón se empleaba para envolver las reliquias de Tezcatlipoca del bulto sagrado o tlaquimilolli en la ciudad de Texcoco que contenía chalchihuites (cuentas de jadeíta) y un hueso de fémur. OLIVIER, 2004, pp. 144-145.
} 
que significa "ojo" o "rostro". Esto me sugiere que pudo haber una intención conceptual entre el dibujo de los dioses y la noción del vocablo ixiptlah entendido como "rostro"72.

\section{Reflexiones finales}

A primera vista, se podría decir que los comitentes tlaxcaltecas cristianizados que encargaron este manuscrito se apropiaron del discurso político-religioso de conquista y dominación en el cual los dioses fueron suprimidos por la imposición del cristianismo con un propósito más bien apologético. Este documento fue precisamente una herramienta retórica para mantener una posición de poder reafirmando el vasallaje al monarca español y para confirmar privilegios para la nobleza tlaxcalteca, por haber sido ellos los aliados de los conquistadores y haber contribuido a la derrota el señorío tenochca, donde en el discurso teológico-político los franciscanos adquirieron un papel protagónico para mediar entre las instancias de los dominadores y las resistencias de los dominados ${ }^{73}$. Se representa una lucha entre dos facciones, donde el conflicto beligerante entre europeos e indígenas, entre conquistados y conquistadores se traslada y se sublima a la dimensión de la psicomaquia entre el bien el mal, tal como se advierte en las Sagradas Escrituras. Por lo tanto, esta lucha se entiende como un designio divino, más allá de las voluntades humanas. La presencia tlaxcalteca en estos dibujos se expresa mediante la figura de jóvenes de la nobleza indígena cristianizados y como excepción del resto de los indígenas adversarios de los conquistadores. Su caracterización apunta a su "inocencia prístina", considerados como neófitos o infantes, tal como argumentaban Motolinía o Bartolomé de las Casas. Pero, además, en este discurso los tlaxcaltecas aparecen como escogidos por la providencia para ser los primeros y nuevos cristianos en la Nueva España. La figura del diablo en el Códice de Glasgow, como adversario del Dios cristiano, fue muy oportuna para personificar a los "otros" indígenas como idólatras, es decir, aquellos que renegaron de la fe de Cristo y no rindieron vasallaje al monarca hispano quien asumía, en estos discursos, el papel de defensor del mundo católico bajo la retórica de la potestas austrica.

Sin embargo, tengo para mí que en estas láminas se entretejió un discurso más complejo y sutil que deja entrever atisbos del nominalismo franciscano durante la evangelización. La idolatría al estar definida en el libro de la Sabiduría como "principio, causa y término de todos los males" siempre se había considerado el peor de los pecados, el medio usado por el diablo, movido por el orgullo y la envida, para engañar a los hombres, tal como lo señalaban Andrés de Olmos y Bernardino de Sahagún. Inclusive el español jesuita José de Acosta (1540-1600) abandona el empirismo y objetividad empleado en su estudio sobre las costumbres indígenas al confrontarse con las "curiosas similitudes" entre las prácticas religiosiosas indígenas y cristianas, que indicaban un origen sobrenatural cuya fuente necesariamente provenía de la envidia y orgullo de Satanás ${ }^{74}$.

Como materialización de esta idea, la imagen del diablo se reflejó en el espejo humeante de Tezcatlipoca. El Señor negro de las burlas y del engaño se transformó, mediante una suerte de mutación iconotrópica, en Luzbel, Príncipe de las Tinieblas. Así pues, los dioses relacionados con las fuerzas nocturnas, los augurios, la muerte y el inframundo adquirieron en este juego de espejos la figura de ángeles caídos. Para los ojos europeos los simulacros de los "falsos dioses", vistos como ídolos, eran máscaras que encubrían el verdadero rostro del diablo para engañar y perder las almas de los indígenas. En el reverso de

\footnotetext{
72 Magaloni, 2013, pp. 11-12. Opté por usar ixiptlah con h al final porque es cuando se usa para referir a "objeto poseído", tal como lo indica Diana Magaloni en su nota 17. También ver Alfredo LóPEz Austin, Hombre-dios: religión y política en el mundo náhuatl, México, Instituto de Investigaciones Históricas, UNAM, 1973, pp. 119-121.

73 BотTA, 2011, p. 49.

74 Cervantes, 1996, pp. 50-51.
} 
este espejo, paradójicamente bajo la mirada indígena, los dioses se revelaban y se hacían presentes mediante su ixiptlah, para así mostrar las verdades ocultas del cosmos. La iconotropía entre dioses-demonios e ídolos-ixiptlah fueron las dos caras de un mismo espejo durante el complejo proceso de la fundación de la Nueva España.

Para Felipe II es probable que los "demonios indianos" en este manuscrito fueran otra curiosidad más de los reinos de ultramar. Pero precisamente esta asimilación iconotrópica entre los dioses y el diablo permitió que las deidades prehispánicas adquirieran un propósito diferente y se adecuaran a los reacomodos en los discursos del poder en un nuevo orden político y religioso. No hay que olvidar que, después de la Conquista, ante las prohibiciones de los antiguos cultos y los pesares sufridos durante el proceso de aculturación, el diablo, en algunos casos generalmente en sitios alejados, se asimiló como una deidad más, pero precisamente por ser "némesis" del Dios cristiano ${ }^{75}$.

Ya sea encubiertos por los atributos de ángeles caídos o como ídolos ardiendo entre las llamas, los dioses antiguos no se resignaron a desaparecer del todo. Por su parte, a lo largo de la historia virreinal el diablo, se asimiló dentro del folklor y de la cultura popular. Tal como se advierte en unos versillos, el Maligno, en su versión ridiculizada, se asoció con el pulque y el chocolate de origen prehispánico, quien también sucumbió a los "diretes" y a los deleites novohispanos:

$$
\begin{gathered}
\text { El diablo se fue a tomar, } \\
\text { y le dieron pulque curado; } \\
\text { de tan sabroso que estaba, } \\
\text { que hasta se quedó tirado. } \\
\text { El diablo se fue a pasear, } \\
\text { y le dieron chocolate; } \\
\text { de tan caliente que estaba, } \\
\text { que hasta se quemó el gaznate }
\end{gathered}
$$

ROSA DENISE FALLENA MONTAÑo es maestra en Museología (ENCRyM). Obtuvo el grado de Maestría y doctorado en Historia del Arte (FFYL, UNAM), con mención honorífica. Desde 2014 es investigadora asociada de tiempo completo en el Instituto de Investigaciones Estéticas, UNAM. Pertenece al Sistema Nacional de Investigadores. Trabajó en el Museo del Templo Mayor, INAH (2001-2003). Coordinó el proyecto "La pintura mural prehispánica en México", IIE, UNAM (2003-2007). Actualmente dirige el proyecto interdisciplinario "Travesías de la mirada devota: Las imágenes religiosas medievales y sus traslados al Nuevo Mundo", IIE, UNAM. Ha publicado varios artículos sobre imágenes religiosas en revistas especializadas, entre los que destaca "Entre destellos se desvanece una devoción: la imagen de oro de la Asunción, patrona de la catedral metropolitana de México" en la revista Colonial Latin America History Review. Está por publicarse su libro La imagen de la Virgen María en la Retórica de Conquista y fundación en los valles centrales de Puebla-Tlaxcala. Ha sido docente en la Universidad Autónoma Benito Juárez de Oaxaca, Universidad de las Américas de Puebla, en el Posgrado de Historia del Arte FFYL-UNAM y en el Instituto de las Humanidades del estado de Illinois.

Email: templo_mayor@yahoo.com.mx

Código ORCID: https://orcid.org/0000-0003-3783-2137

\footnotetext{
75 Ibidem, pp. 74-75.

76 Anónimo, Cancionero del folklor mexicano, IV, 9826-9827.
} 